\title{
Using 1D HEC-RAS Modeling and LiDAR Data to Improve Flood Hazard Maps Accuracy: A Case Study from Jijia Floodplain (NE Romania)
}

\author{
Elena Huţanu ${ }^{1}$, Alin Mihu-Pintilie ${ }^{2, *(\mathbb{D})}$, Andrei Urzica ${ }^{1}$, Larisa Elena Paveluc ${ }^{1,3}$, \\ Cristian Constantin Stoleriu ${ }^{1}$ and Adrian Grozavu ${ }^{1}$ (D) \\ 1 Department of Geography, Faculty of Geography and Geology, Alexandru Ioan Cuza University of Iaşi, Bd. \\ Carol I 20A, 700505 Iaşi, Romania; hutanu.elena@yahoo.com (E.H.); urzica.andrei94@gmail.com (A.U.); \\ larisapaveluc@gmail.com (L.E.P.); cristoan@yahoo.com (C.C.S.); adriangrozavu@yahoo.com (A.G.) \\ 2 Science Research Department, Institute for Interdisciplinary Research, Alexandru Ioan Cuza University \\ of Iaşi, St. Lascăr Catargi 54, 700107 Iaşi, Romania \\ 3 Siret Water Basin Administration, St. Cuza Voda 1, 600274 Bacău, Romania \\ * Correspondence: alin.mihu.pintilie@mail.uaic.ro or mihu.pintilie.alin@gmail.com; Tel.: +40-741-912-245
}

Received: 24 April 2020; Accepted: 3 June 2020; Published: 6 June 2020

\begin{abstract}
The ability to extract flood hazard settings in highly vulnerable areas like populated floodplains by using new computer algorithms and hydraulic modeling software is an important aspect of any flood mitigation efforts. In this framework, the 1D/2D hydraulic models, which were generated based on a Light Detection and Ranging (LiDAR) derivate Digital Elevation Model (DEM) and processed within Geographical Information Systems (GIS), can improve large-scale flood hazard maps accuracy. In this study, we developed the first flood vulnerability assessment for 1\% (100-year) and $0.1 \%$ (1000-year) recurrence intervals within the Jijia floodplain (north-eastern Romania), based on 1D HEC-RAS hydraulic modeling and LiDAR derivate DEM with $0.5 \mathrm{~m}$ spatial resolution. The results were compared with official flood hazards maps developed for the same recurrence intervals by the hydrologists of National Administration "Romanian Waters" (NARW) based on MIKE SHE modeling software and a DEM with $2 \mathrm{~m}$ spatial resolutions. It was revealed that the 1D HEC-RAS provides a more realistic perspective about the possible flood threats within Jijia floodplain and improves the accuracy of the official flood hazard maps obtained according to Flood Directive 2007/60/EC.
\end{abstract}

Keywords: HEC-RAS river analysis system; high-density LiDAR data; 1D modeling; flood hazard maps; Jijia floodplain

\section{Introduction}

In the last few decades, with climate change and global warming, catastrophic flood events have been frequently recorded all over the world and central-eastern Europe, including Romania, was no exception [1-7]. In this regard, north-east Romania, drained by the Siret and Prut rivers which together have the largest river basins in the country, is one of the most vulnerable territories [8]. For example, approximately at intervals of two years in the last 20 years (post-2000), major flood events have occurred and became a constant threat to urban and rural settlements located within the floodplains of the main rivers [9]. Generally, the most catastrophic floods events were caused by heavy rains [10,11], but their impact was also amplified by the inefficient river regulation measures [12,13], the intensification of deforestation [14], and/or housing development within the floodplain areas $[15,16]$. Also, in some cases, the impact and damage caused by floods were determined by the incapacity of the local authorities to implement efficient planning policies (e.g., achievement of flood hazard maps with high accuracy). 
However, since 2007, when Romania joined the European Union, flood risk maps have been compiled under the Flood Directive 2007/60/EC of the European Council [17-19].

In this framework, the ability to generate flood hazard maps based on new computer algorithms and hydraulic modeling software and integrating the results within a Geographical Information Systems (GIS) database are important foundations for any flood mitigation efforts $[9,20,21]$. In this context, there are many scientific studies that used different hydraulic modeling applications and GIS tools (e.g., LISFLOOD-FP, MIKE SHE, HEC-RAS) designed to simulate floodplain inundation in a computationally efficient manner over complex topography [22-31]. Thereby, due to the recent computational upgrades of the Hydrologic Engineering Center-River Analysis System (HEC-RAS 5.0.7.), a software developed by the U.S. Army Corps of Engineers Hydrologic Engineering Center (USACE HEC, Davis, CA, USA) [32], this integrated hydrological modeling system proved to be the most efficient application. For example, due to the 1D, 2D, and combined 1D-2D stream flow modeling capability, the HEC-RAS software is the most widely used tool within flood hazard and risk mapping studies [33-40], for real time flood forecasting [41,42], and even for remodeling past flood events [16]. However, in Romania, the official flood hazard maps designed under Flood Directive 2007/60/EC by the hydrologists of National Administration "Romanian Waters" (NARW) were made using the MIKE SHE software, which provided results that are quite similar to the HEC-RAS application $[43,44]$.

In this study, we developed the first flood vulnerability assessment for floods with $1 \%$ (100-year) and $0.1 \%$ (1000-year) recurrence intervals within the Jijia floodplain (north-eastern Romania), based on a Light Detection and Ranging (LiDAR) derivate Digital Elevation Model (DEM) with $0.5 \mathrm{~m}$ spatial resolution and 1D HEC-RAS hydraulic modeling, and we compared the results with official flood hazards maps developed by NARW for the same recurrence intervals, based on $2 \mathrm{~m}$ spatial resolutions LiDAR derivate DEM and MIKE SHE modeling software. We used the 1D HEC-RAS modeling instead of 2D HEC-RAS modeling because a 1D hydraulic method gives good results in cases of flood propagation along the main river, as in the area studied by us [45-47]. The 2D models are recommended in cases when the water is expected to overtop levees and the flow direction may change, spreading across a large area [48,49]. The field evidences were collected in several sections of the study area and consisted of GPS measurements of traces left by floods on the walls of houses, fences, and bridge pillars. Thereby, the main objective of this study is to assess the effects of $0.5 \mathrm{~m}$ and $2 \mathrm{~m}$ LiDAR based DEM resolutions in simulating the flood extent, inundation depth, and flood hazard pattern. This type of research corresponds with more than five years collaboration between researchers and $\mathrm{PhD}$ students within the Doctoral School of Geosciences, University "Alexandru Ioan Cuza" of Iaşi (UAIC), Romania and the specialists of Prut-Bîrlad Water Administration (PBWA) within NARW, in the field of hydrological risk assessment and improvement of flood hazard perception in north-eastern Romania [8-12,14-16,19,50]. The results led to a more realistic perspective on the possible flood threats within the Jijia floodplain and improved the accuracy of the official flood hazard maps designed according to the Flood Directive 2007/60/EC.

\section{Study Area}

\subsection{Hydro-Geomorphological Framework}

The Jijia River is located in the north-eastern part of Romania (watershed centroid: $47^{\circ} 30^{\prime} \mathrm{N}, 27^{\circ} \mathrm{E}$ ) and is the main tributary right-bank of the Prut River (Figure 1a,b). From a morphological point of view, the Jijia river basin $\left(5757 \mathrm{~km}^{2}\right)$ overlaps the lower area of the Moldavian Plateau, also known as the Jijia Plain [50] (Figure 1c). The general morpho-structural context consists of a monocline (dipping strata from NW to SE) formed by a succession of thicker sandy clay deposits and thin layers of limestone and sandstone of Lower and Medium Sarmatian age [51]. Over these, a loess layer with thicknesses between 1-2 m (most frequently) and 15-30 m (e.g., cuesta slopes, fluvial terraces) covers the entire study area [52]. The Jijia floodplain is characterized by recent (Holocene) alluvial deposits accumulated in the last 10,000 years, approximately. Characteristic landforms are well-contoured valleys separated 
by interfluves that are most often of the cuesta type [51]. Elevations range between $18 \mathrm{~m}$ and $584 \mathrm{~m}$, the average slope angle is $5.09^{\circ}$ (maximum value $>38^{\circ}$ for active river banks consumed by erosion), and relief energy does not exceed $150 \mathrm{~m} / \mathrm{km}^{2}-200 \mathrm{~m} / \mathrm{km}^{2}$ within the Jijia basin [22,50] (Figure 1c).

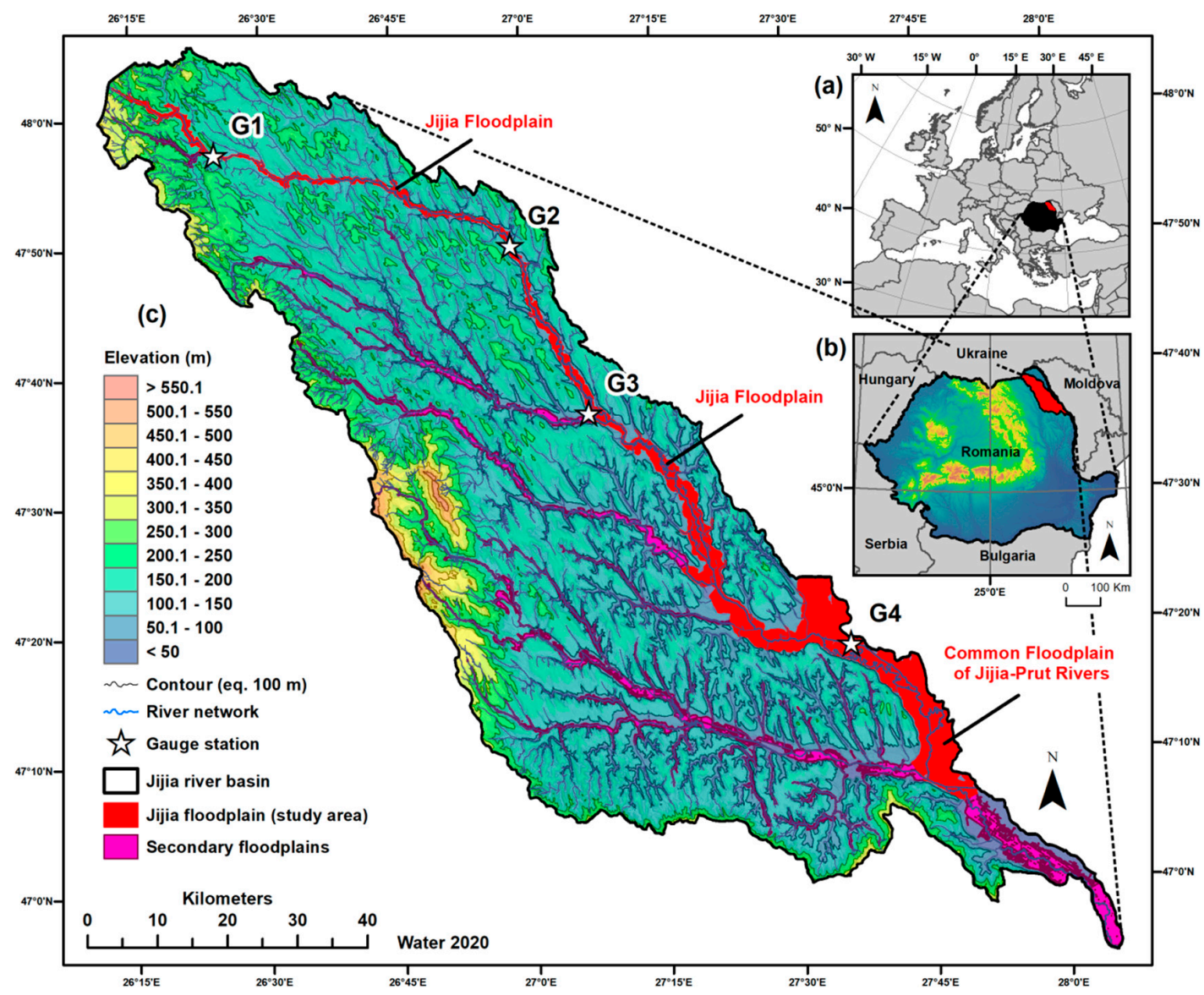

Figure 1. Geographical location of the Jijia river basin in (a) eastern Europe and (b) north-eastern Romania (Jijia Plain); (c) Location of the Jijia floodplain (see Figure 2.) within the Jijia river basin and the gauging stations (G1: Dorohoi; G2: Dangeni; G3: Todireni; G4:Victoria) used for 1D HEC-RAS modeling.

From a hydrographical point of view, Jijia River springs in Bour Mountain (Ukraine) from a relative altitude of $410 \mathrm{~m}$, flows south, and meets the Prut River at a relative altitude of $18 \mathrm{~m}$ on the territory of Iași County (Romania). The main hydrometric characteristics of Jijia River are: $287 \mathrm{~km}$ of total watercourse length, of which $12 \mathrm{~km}$ is in Ukraine and $275 \mathrm{~km}$ in Romania, 1\%o average longitudinal slope, 1.45 sinuosity coefficient, and $152 \mathrm{~m}$ average altitude of the water surface [50]. The major tributaries of the Jijia River are the Sitna, Miletin, and Bahlui rivers [50,51]. Climate conditions, characterized by a mean annual air temperature between $9{ }^{\circ} \mathrm{C}-9.5{ }^{\circ} \mathrm{C}$ (63 year monitoring period between 1955-2018) and multi-annual average precipitations between 550-600 mm (63 year monitoring period between 1955-2018), control 60\% of the water flow rate and are often overtaken in transition seasons and in periods with maximum rainfall [53]. Thereby, the multi-annual average discharge is $10 \mathrm{~m}^{3} / \mathrm{s}$ (316,000,000 m³/year), with fluctuations between $0.519 \mathrm{~m}^{3} / \mathrm{s}$ and $71.06 \mathrm{~m}^{3} / \mathrm{s}$ [5]. The historical maximum discharge was $397 \mathrm{~m}^{3} / \mathrm{s}$ and has been recorded in the lower sector of the Jijia at Todireni gauge station in 17 July 1969 [15,50,53]. Other historical flood events associated with high discharges occurred on: 15 July $\left.1955-303 \mathrm{~m}^{3} / \mathrm{s}\right), 11$ June $1975-141 \mathrm{~m}^{3} / \mathrm{s}, 13$ April 1979-192 m³ 9 April $1980-147 \mathrm{~m}^{3} / \mathrm{s}$, and 7 June $1991-78 \mathrm{~m}^{3} / \mathrm{s}$ ) [50,53]. 


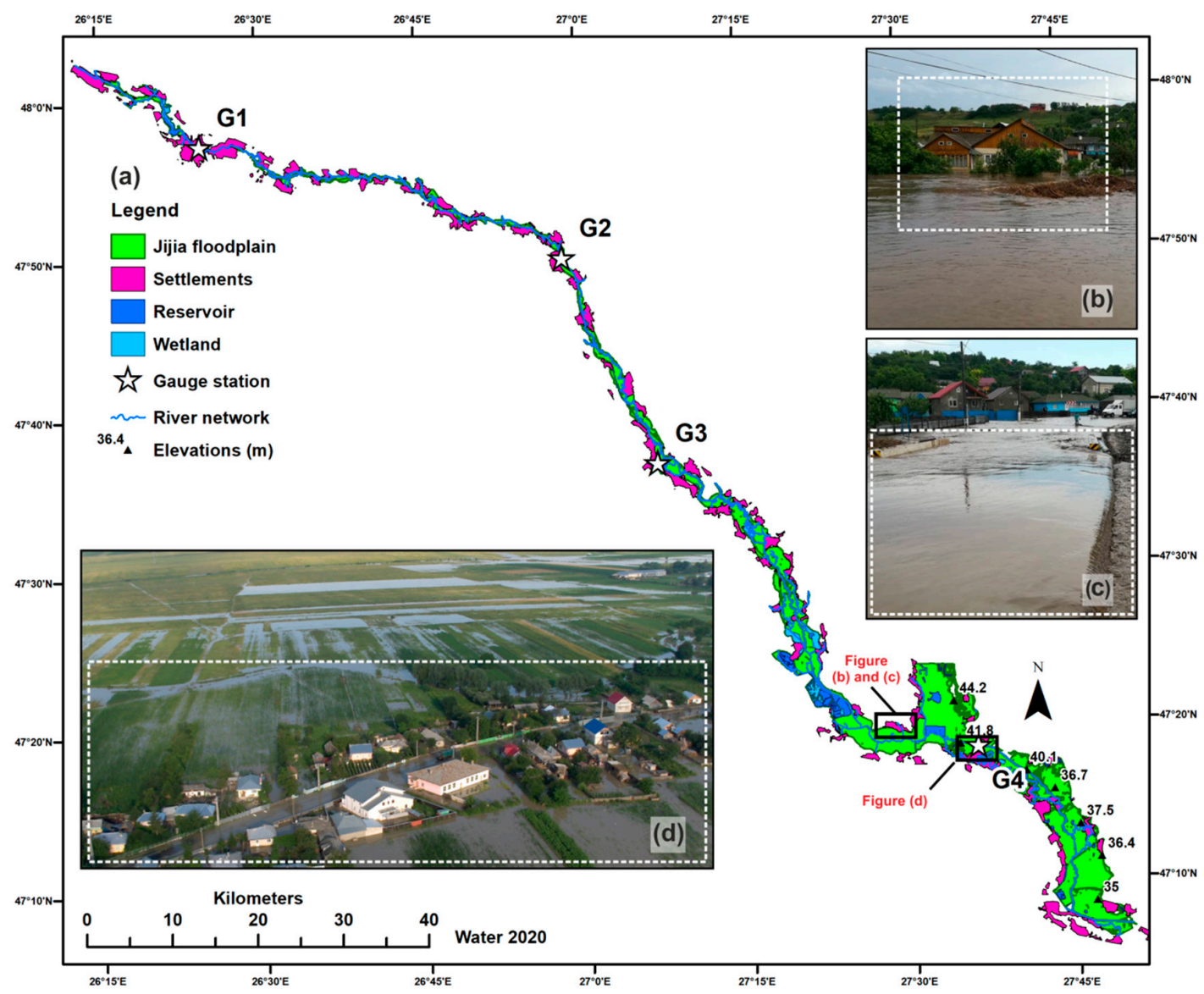

Figure 2. (a) Habitation characteristics in the Jijia floodplain vs. flood hazards: (b) houses and (c) roads affected by a flash flood that occurred in Mihail Kogalniceanu settlement (lower sector of the Jijia floodplain) on 15 April 2018; (d) traces of a flood event that occurred in the summer of 2008 and affected the rural settlements from the common floodplain of the Jijia-Prut rivers.

\subsection{Habitation in The Jijia Floodplain}

There are 76 settlements within the floodplain of the Jijia River and the watercourse either passes through them or runs in their close vicinity, which leads to a high flood hazard (Figure 2). Among all settlements, only Dorohoi is of urban status and the remaining 75 are all rural localities (villages or commune residences). According to the latest demographic studies and national census [54], in the Jijia floodplain, there are 92,826 inhabitants, of which 24,309 inhabitants are only in Dorohoi City, and the population density is 653.06 inhabitants $/ \mathrm{km}^{2}$ (2630 inhabitants $/ \mathrm{km}^{2}$ in Dorohoi) [54]. Concerning the causes and extent of flood hazard within the inhabited territory of the Jijia floodplain, the most catastrophic events took place due to intense anticyclone activity in the June-July interval [55]. The last example is the flash flood which took place in 2018 (Figure $2 b, c$ ) as a result of heavy rains generated by the intense activity of Azores anticyclone and its influence on Eastern Europe [19]. Overall, being a typical rural area highly dependent on subsistence agriculture by family farming or small-scale fisheries, the Jijia floodplain is heavily affected by hydrological disasters, especially in terms of material losses and trauma population [50,51,53] (Figure 2d).

\section{Database and Methodology}

Figure 3 summarizes the workflow chart followed in this study with the hydrological, LiDAR derived DEM, official flood maps (Figure 3a), and built-up data acquisition process (Figure 3b); the key steps for 1D HEC-RAS flood modeling and validation of streamflow accuracy based on average discharge (Figure 3c); comparison between 1D HEC-RAS flood extents and official flood extents 
(Figure 3d); flood hazards assessment based on Ministry of Land Infrastructure and Transport (MILT) criteria in Japan using 1D HEC-RAS models and official flood hazard maps (Figure 3e).

(a)

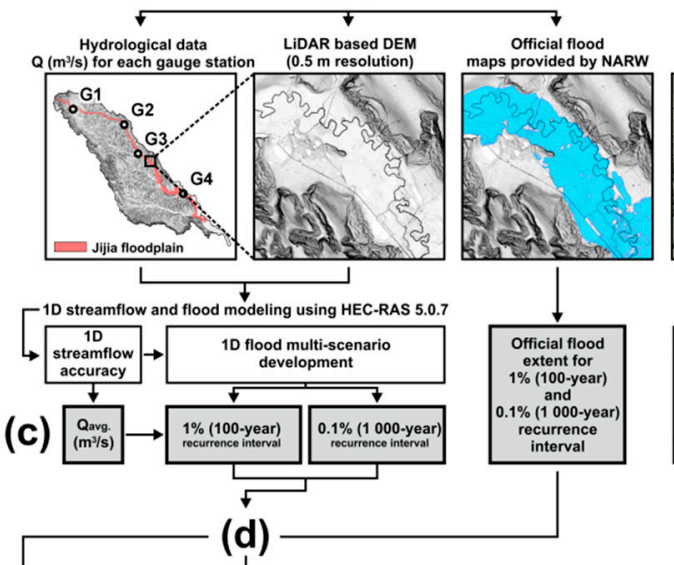

(b)
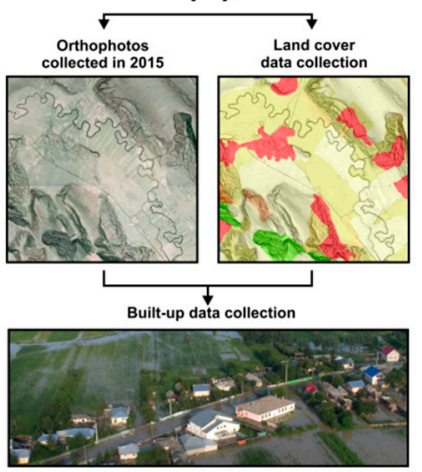

$\downarrow$

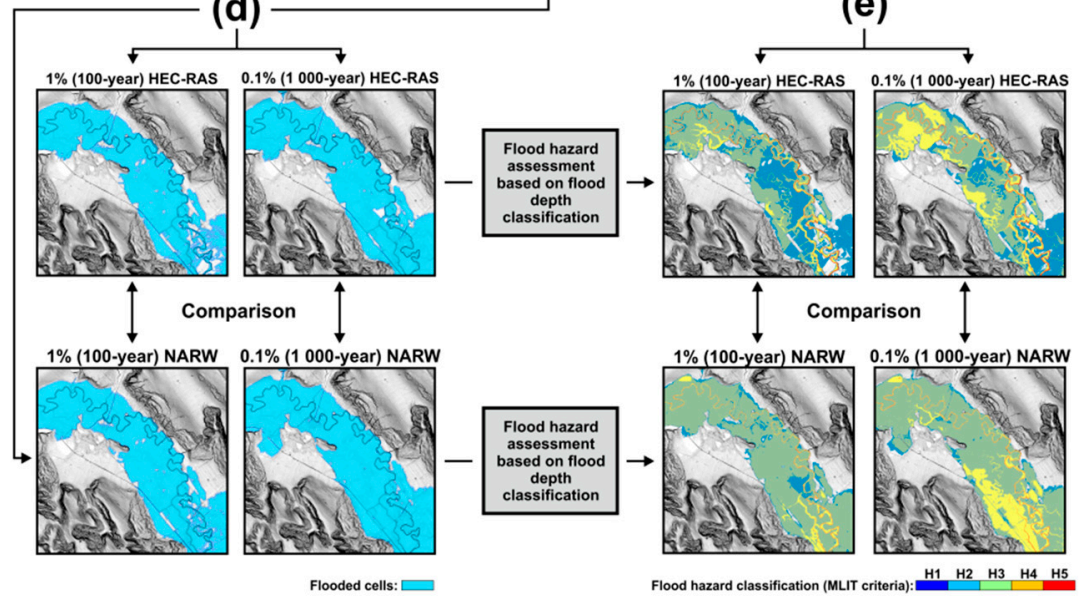

Figure 3. Workflow chart followed in this study: (a) obtaining the hydrological data recorded at each gauge station within the Jijia floodplain (G1, G2, G3, and G4), LiDAR based DEM (0.5 m spatial resolution) data, and the official flood hazard maps with $1 \%$ (100-year) and $0.1 \%$ (1000-year) recurrence interval probabilities used for 1D HEC-RAS modeling process and flood hazard comparison; (b) manual digitization of land cover classes and built-up areas using high resolution orthophotos for flood hazard assessment; (c) 1D HEC-RAS multi-scenario development with 1\% (100-year) and 0.1\% (1000-year) recurrence interval probabilities, where $Q_{a v g}$ was generated based on average discharge for $1 \mathrm{D}$ stream flow accuracy; (d) comparison between 1D HEC-RAS flood extents and official flood extents provided by NARW with $1 \%$ (100-year) and $0.1 \%$ (1000-year) recurrence interval probabilities; (e) flood hazard assessment based on the built-up data and flood depth classification according to the MILT and comparison between 1D HEC-RAS hazard models and official flood hazard maps with 1\% (100-year) and $0.1 \%$ (1000-year) recurrence interval probabilities.

\subsection{Data Acquisition}

\subsubsection{LiDAR Data}

The LiDAR data was obtained from NARW-Prut-Bîrlad Water Administration (PBWA) and consisted of 23,832 raster files generated on the basis of raw ground point elevation data collected using airborne LiDAR technology at spatial density between 16 point $/ \mathrm{m}^{2}$ (built-up areas) and 4 point $/ \mathrm{m}^{2}$ (outside built-up areas) [43] (Figure 3a). The point data cloud was filtered to exclude vegetation or another type of not terrain surface point (e.g., man-made features) by the producer. A DEM with $0.5 \mathrm{~m}$ spatial resolutions used for 1D HEC-RAS modeling within this study was generated by spatial processing in the ArcGIS 10.2 software of LiDAR raster files. Thereby, a raster dataset was created 
into a geodatabase to merge the LiDAR geotiffs and additionally to reduce the errors generated by the merging process; the unified DEM was filtered using specific commands from ArcToolbox (e.g., flow direction, sink, fill) [56]. Also, because the raster filtering highlights the null elevation values, we made their correction based on local and regional topography [12].

\subsubsection{Hydrological Data}

The hydrological data used in this study were obtained from the PBWA (Iaşi branch) and consisted of flow and water levels data recorded at four main gauging stations $\left(G_{1}, G_{2}, G_{3}\right.$, and $\left.G_{4}\right)$ located on the Jijia River: $G_{1}$ Dorohoi-Monitoring period 50 years (1968-2018), $G_{2}$ Dangeni-Monitoring period 49 years (1969-2018), $\mathrm{G}_{3}$ Todireni-Monitoring period 49 years (1969-2018), and $\mathrm{G}_{4}$ Victoria-Monitoring period 63 years (1955-2018) (Figure 3a). After the hydrological data acquisition stage, the $Q_{\max }\left(\mathrm{m}^{3} / \mathrm{s}\right)$ flow rates corresponding to the $1 \%$ (100-year) and $0.1 \%$ (1000-year) recurrence intervals based on the discharge recorded at each gauging station were needed [57]. The calculations consisted of determining the probability of empirical overflow according to Weibull's formula (Equation (1)) [58] and the recurrence intervals' probability of unregistered flows based on the Person III formula (Equation (2)) [59]. The peak flow obtained for each gauging station $\left(\mathrm{G}_{1}, \mathrm{G}_{2}, \mathrm{G}_{3}\right.$, and $\mathrm{G}_{4}$ ) was the same as the one obtained by the NARW (Table 1).

$$
P_{i}=i /(n+1) \times 100,
$$

where $P_{i} \%$ is the probability of the occurrence of a measured flow, $i$ is the order number of the orderly increasing flow, and $n$ is the total number of terms of the string.

$$
Q_{p \%}=Q_{a v g .} \times\left(1+C_{v} \times \vartheta_{p \%}\right)
$$

where $Q_{p}$ is the recurrence interval of flow, $Q_{a v g}$ is the mean flow, $C_{v}$ is the coefficient of variation, and $\vartheta_{p \%}$ is the order of the insurance curve for $C v=1$.

Table 1. The $Q_{\max }\left(\mathrm{m}^{3} / \mathrm{s}\right)$ flow rates and the recurrence intervals probabilities estimated using the Weibull and Pearson type III distribution curve for each gauging station $\left(\mathrm{G}_{n}\right)$ on the Jijia River between

\begin{tabular}{|c|c|c|c|c|c|c|c|}
\hline \multirow{2}{*}{ River } & \multirow{2}{*}{$\begin{array}{l}\text { Gauging } \\
\text { Station }\end{array}$} & \multirow{2}{*}{${ }^{1}$ Latitude } & \multirow[t]{2}{*}{${ }^{1}$ Longitude } & \multirow{2}{*}{$\begin{array}{c}\text { Date of } \\
\text { Occurrence }\end{array}$} & \multirow{2}{*}{${ }^{2} Q_{\max .}\left(\mathrm{m}^{3} / \mathrm{s}\right)$} & \multicolumn{2}{|c|}{$\begin{array}{c}{ }^{2} Q_{\max .}\left(\mathrm{m}^{3} / \mathrm{s}\right) \\
\text { Recurrence Intervals }\end{array}$} \\
\hline & & & & & & $31 \%$ & ${ }^{4} 0.1 \%$ \\
\hline \multirow{4}{*}{ Jijia } & $\mathrm{G}_{1}$-Dorohoi & 26.4101 & 47.9557 & 24 June 1985 & 170 & 211.49 & 356.16 \\
\hline & $\mathrm{G}_{2}$-Dangeni & 26.9732 & 47.8319 & 13 July 1969 & 155 & 174.71 & 261.18 \\
\hline & $\mathrm{G}_{3}$-Todireni & 27.1156 & 47.6139 & 17 July 1969 & 397 & 286.45 & 471.34 \\
\hline & $\mathrm{G}_{4}$-Victoria & 27.6003 & 47.3079 & 21 July 1969 & 325 & 303.95 & 478.46 \\
\hline
\end{tabular}
1969 and 2018.

${ }^{1}$ WGS 84 decimal degree projection; ${ }^{2} Q_{\max }$. $\left(\mathrm{m}^{3} / \mathrm{s}\right)$-Maximum flow rates recorded at $\mathrm{G}_{1}, \mathrm{G}_{2}$, and $\mathrm{G}_{3}$ gauging stations between 1969 and 2015, and maximum flow rates recorded at $G_{4}$ gauge station between 1955 and $2015 ;{ }^{3} Q_{\max }\left(\mathrm{m}^{3} / \mathrm{s}\right)$ estimated for 100 year $(1 \%)$ and ${ }^{4} Q_{\max } .\left(\mathrm{m}^{3} / \mathrm{s}\right)$ estimated for 1000 year $(0.1 \%)$ recurrence intervals.

\subsubsection{Land Use on Built-Up Areas Data}

Land used data acquisition for flood hazard assessment within the Jijia floodplain was carried out in two stages. The first step consisted of on-screen digitizing within the ArcGIS 10.2 of land use polygons based on orthophotos collected in 2015. For improving land use data accuracy obtained by the manual digitization method, the results were adjusted where appropriate according to the European Riparian Zone database developed within the Copernicus Land Monitoring Service (CLMS) project [60]. The second step consisted of on-screen digitizing within the ArcGIS 10.2 of built-up areas (e.g., houses, attachment buildings, administrative buildings) with a $20 \mathrm{~m}^{2}$ minimum mapping unit based on various spatial databases (e.g., orthophotos 2015, OpenStreetMap) [61] (Figure 3b). 
All resulted features were unified and classified into land use categories according to Corine Land Cover specification (CLC 2018) [62], in conjunction with the National Agency for Cadastral and Land Registration of Romania classification for built-up areas.

\subsubsection{Official Flood Hazard Data}

The official flood hazard data developed for 10\% (10-year), 1\% (100-year), and 0.1\% (1000-year) recurrence intervals were generated by specialists of PBWA within the first stage of Flood Directive 2007/60/EC implementation in Romania [17-19]. For the north-eastern part of the country, which includes the Jijia floodplain, this action corresponded with the implementation of the project Works for reducing the flood risk in Prut-Bîrlad Basin [43]. Thereby, the hydrological modeling was realized using the Mike 11 Rainfall-runoff (RR) software tool at the medium-scale river basins. For the 1D hydraulic modeling, the Mike 11 Hydrodynamics (HD) software tool was used based on discharge function $(Z=f(Q))$ and $2 \mathrm{~m}$ spatial resolutions LiDAR derivate DEM. In this study, to evaluate the difference between 1D HEC-RAS and official 1D Mike flood hazard models, only 1\% (100-year) and $0.1 \%$ (1000-year) recurrence interval scenarios generated based on official peak flow values (Table 1) were used (Figure 3a,d).

\section{2. $1 D$ HEC-RAS Modeling}

The 1D flood hazard models for 1\% (100-year) and 0.1\% (1000-year) recurrence intervals were generated using the open source HEC-RAS 5.0.7. software developed by USACE HEC since 1993 and the HEC-GeoRAS 10.2., an auxiliary module for ArcGIS 10.2. As mentioned above, this method has multiple applications in 1D and 2D water flow simulation, sediment transport modeling, and space-time flood evolution [63]. Most frequently, 1D HEC-RAS modeling is used for the assessment of flood-prone areas and statistical analysis of flood occurrence within the floodplain of small-scale and medium-scale catchment basins [64]. Thereby, for 1D HEC-RAS modeling within the Jijia floodplain, three steps were followed (Figure 3a):

- $\quad$ Step one-this pre-processing stage involved the manual digitization of thematic vector layers (e.g., river network, stream centerline, river banks, flow paths, cross sections) in ArcGIS 10.2. software based on orthophotos collected in 2015 and LiDAR based DEM with $0.5 \mathrm{~m}$ spatial resolutions, and generation of the attribute table for each of them. Based on hydrological and geomorphological rules (e.g., spring to spill, from left bank to right bank, perpendicular to the thalweg, no intersection between cross sections), more than 1700 cross sections with 150-300 m intervals between them were manually digitized.

- Step two (Figure 4) - this processing stage involved the import of the required parameters (e.g., Manning roughness coefficient, hydrological data) into HEC-RAS software to run the 1D flood simulation. Thereby, the Manning roughness coefficient $(n)$ was calculated based on land use classes for each cross section, stream centerline, and river bank intersections (built-up area: $n=0.3$; roads: $n=0.014$; vegetated open space areas: $n=0.05$; arable land: $n=0.025$; pasture: $n=0.035$; broad-leaved forest: $n=0.1$; transitional woodland-shrub: $n=0.06$; water surface: $n=0.04$; degraded land: $n=0.08$ [64]. The flow rates were calculated using Weibull's (Equation (1)) and the Pearson III (Equation (2)) for 1\% (100\%) and 0.1\% (1000-year) recurrence intervals (Table 1). The 1D flood simulations based on St. Venants continuity equation (Equation (3)), which describes the preservation of mass in a given control volume, were computed with steady flow data and the boundary condition was set for normal depth at 0.7 [12]. We used a steady flow analysis instead of unsteady flow analysis because in the second case, the HEC-RAS software needs a hydrograph, which we could not obtain from the local authorities. Thereby, to overcome this limitation, we used the flow rate for each gauging station, similar to official flood hazard data.

$$
\frac{\partial(Q)}{\partial x}+\frac{\partial A}{\partial t}+q=0,
$$


where $Q$ is the flow rate, $A$ is the cross-sectional area, and $q$ is the lateral inflow.

- $\quad$ Step three-this post-processing stage involved exporting the 1D HEC-RAS results to the ArcGIS software and generating the flood patterns with 1\% (100-year) and 0.1\% (1000-year) recurrence intervals. The validation of the results was performed by comparing the real discharge recorded at each gauging station with the computed discharge hydrographs.

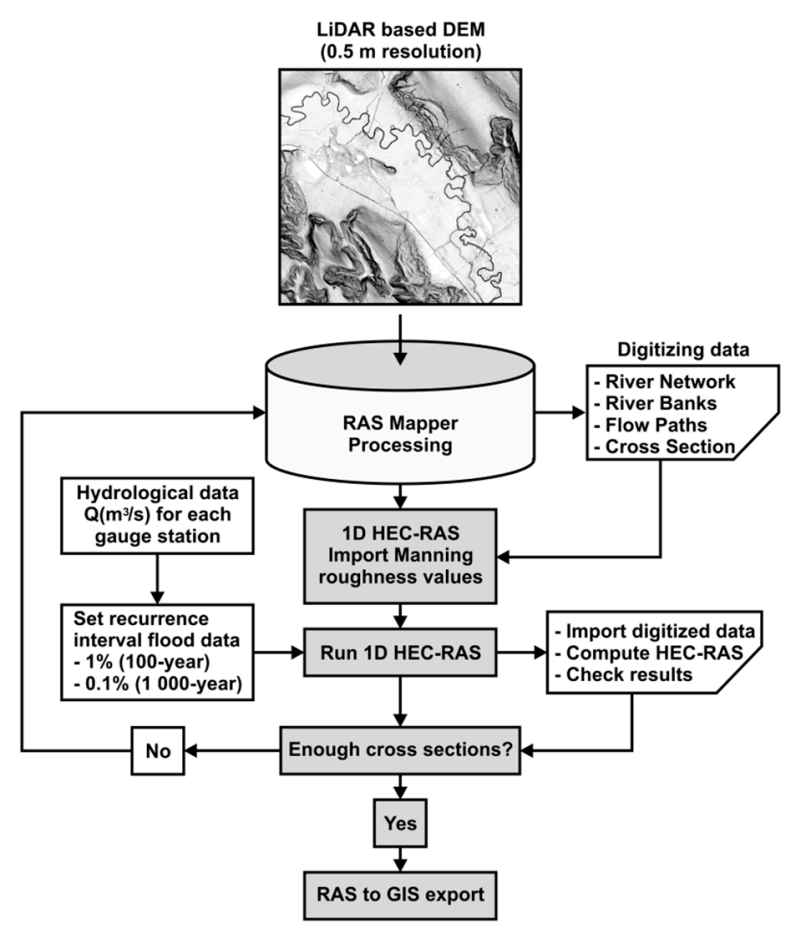

Figure 4. Methodological framework and detailed key steps followed for 1D HEC-RAS flood modeling and flood hazard mapping.

\section{Results and Discussion}

\subsection{D HEC-RAS Flood Pattern with $1 \%$ and $0.1 \%$ Recurrence Intervals}

The 1D modeling performed with HEC-RAS 5.0.7 version offered various output in terms of detailed mapping of flood characteristics within the RAS mapper features. Following the 1\% (100-year) and $0.1 \%$ (1000-year) recurrence interval scenarios, individual layers of the flooded areas in the Jijia floodplain regarding the flood extent and depth were exported. Based on these two flood characteristics, the flood vulnerability assessment was performed using the hazard classification according to the criteria of the Japanese Ministry of Land Infrastructure and Transport (MLIT) [65].

\subsubsection{Flood Extent}

The flood extent layer consists of an inundation boundary layer in a shapefile format which captured the potentially affected areas by floods with 1\% (100-year) and $0.1 \%$ (1000-year) recurrence intervals (Figure 5). According to the 1\% (100-year) recurrence interval scenario, an area of $195.92 \mathrm{~km}^{2}$ within Jijia floodplain is potentially flooded and 2084 buildings are also potentially affected. In the $0.1 \%$ (1000-year) recurrence interval scenario, the total flood extent covers a $251.82 \mathrm{~km}^{2}$ area and 2928 buildings are located in the potentially flooded areas (Table 2). Overall, in the first 1D HEC-RAS scenario (1\%), the flood extent affected only the built-up areas located near the Jijia River (e.g., river banks, lakeshores, wetlands proximity) and in the second 1D HEC-RAS scenario (0.1\%), the flood extent affected the entire Jijia floodplain, except for some areas that are protected by the recent hydrotechnical works (e.g., dams, drainage channels, polders) (Figure 5a-c). 


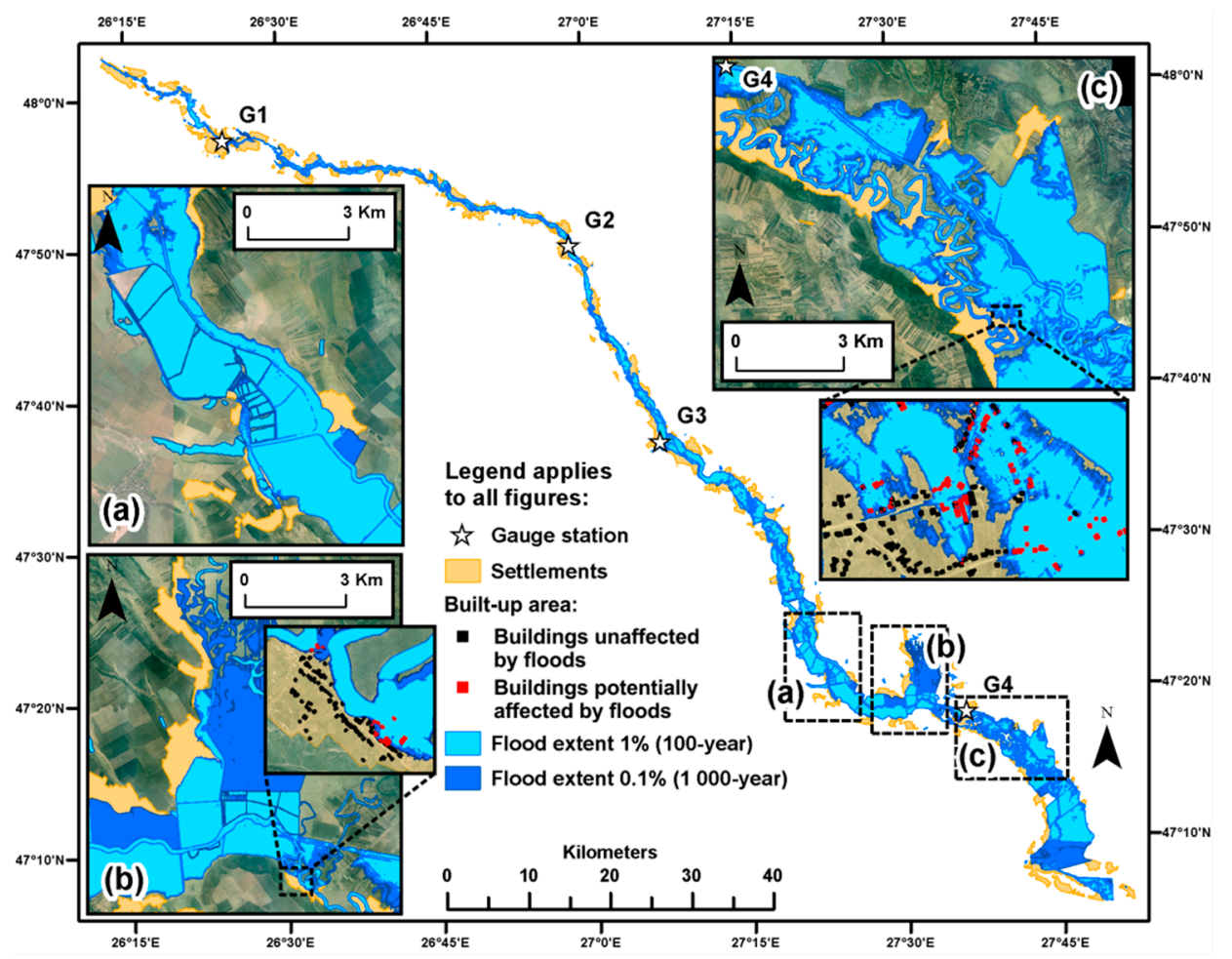

Figure 5. Flood extent derived from the 1D HEC-RAS modeling based on LiDAR data (0.5 m spatial resolution) and $Q_{\max }\left(\mathrm{m}^{3} / \mathrm{s}\right)$ flow rates with $1 \%$ (100-year) and $0.1 \%$ (1000-year) recurrence intervals estimated for each gauging station (G1, G2, G3, and G4). Significant differences between 1\% (100-year) and $0.1 \%$ (1000-year) flood extents are highlighted in the sections $(\mathbf{a}-\mathbf{c})$.

Table 2. Flood extent area and number of buildings potentially affected by floods computed for each $1 \%$ (100-year) and 0.1\% (1000-year) recurrence interval scenarios using 1D HEC-RAS modeling.

\begin{tabular}{cccc}
\hline Flood Extent & $\mathbf{1 \%}(\mathbf{1 0 0}-$ Year) & $\mathbf{0 . 1 \%}(\mathbf{1 0 0 0}-$ Year) & $\mathbf{1}$ Differences \\
\hline Total flood extent $\left(\mathrm{km}^{2}\right)$ & 195.92 & 251.82 & 55.9 \\
${ }^{2}$ Number of affected buildings & 2084 & 2928 & 844 \\
\hline
\end{tabular}

${ }^{1}$ The values indicate the increase from $1 \%$ (100-year) recurrence interval scenario to $0.1 \%$ (1000-year) recurrence interval scenario of flood extent area and number of buildings potentially affected by floods. ${ }^{2}$ About $95 \%$ of all potentially affected buildings are single storey houses built of bricks and/or clay bricks.

\subsubsection{Flood Depth}

The 1D flood depth pattern for 1\% (100-year) and 0.1\% (1000-year) recurrence intervals were generated by taking into consideration the maximum depth for each cell within inundated areas (Figures 6 and 7). According to the 1\% (100-year) recurrence interval scenario, 96.88\% of the built-up area (2019 buildings) is potentially affected by floods that do not exceed $1 \mathrm{~m}$ depth and the remaining $3.12 \%$ of the built-up area (65 buildings) is potentially affected by floods with depths between $1 \mathrm{~m}$ and $5 \mathrm{~m}$. In the case of the $0.1 \%$ (1000-year) recurrence interval scenario, $96.72 \%$ of the built-up area (2832 buildings) is potentially affected by floods that do not exceed $1 \mathrm{~m}$ depth and the remaining $3.28 \%$ of the built-up area (96 buildings) is potentially affected by inundations between $1 \mathrm{~m}$ and $5 \mathrm{~m}$ (Table 3 ). Due to the Jijia floodplain morphology (e.g., $1 \%$ o average longitudinal slope), there are no significant differences between 1\% (100-year) (Figure 6a-c) and 0.1\% (1000-year) (Figure 7a-c) recurrence interval scenarios in terms of inundation depths, except the $<1.0 \mathrm{~m}$ and $1.0-2.0 \mathrm{~m}$ flood depth classes (Table 3). 


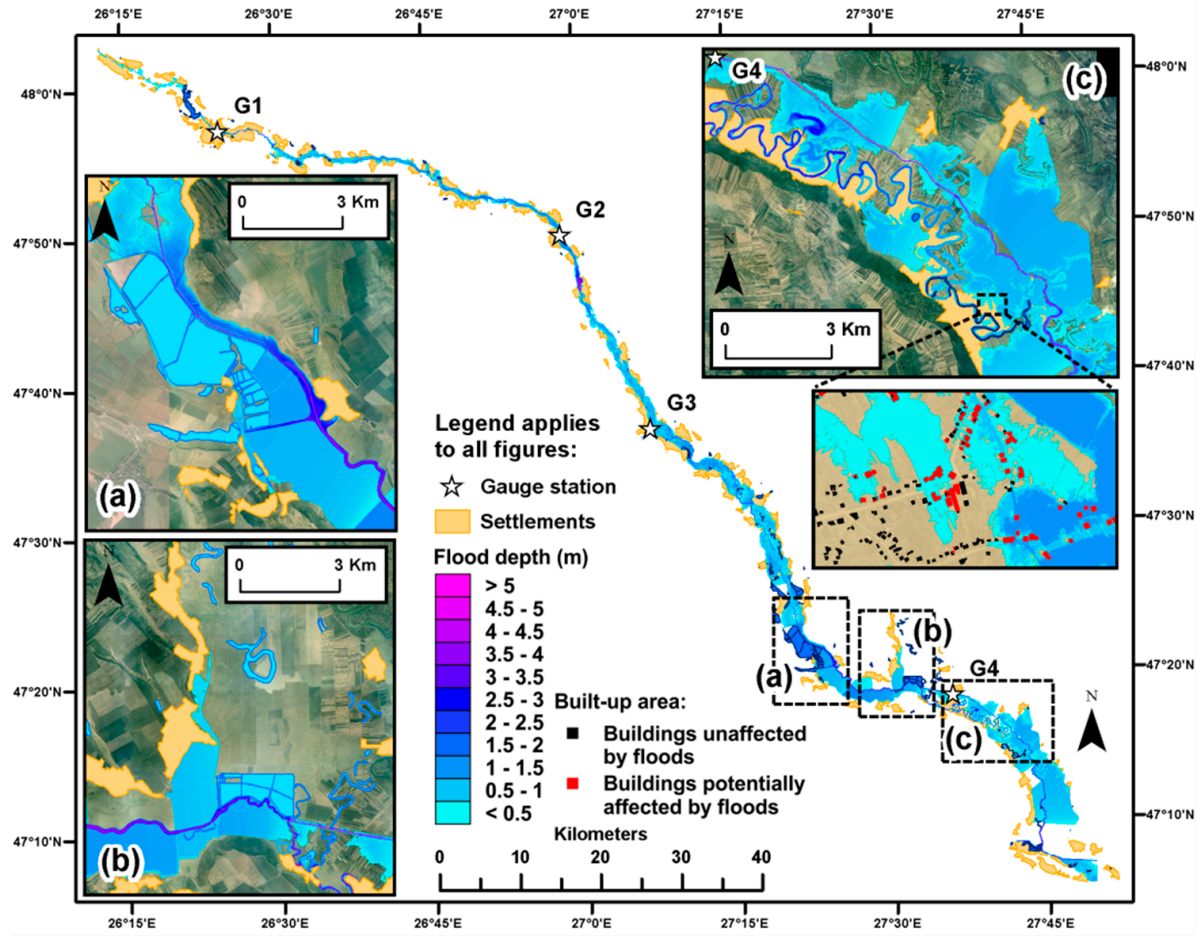

Figure 6. Flood depth derived from 1D HEC-RAS modeling based on LiDAR data (0.5 m spatial resolution) and $Q_{\max } .\left(\mathrm{m}^{3} / \mathrm{s}\right)$ flow rates with $1 \%$ (100-year) recurrence intervals estimated for each gauging station (G1, G2, G3, and G4). The 1\% (100-year) flood depth pattern is highlighted in the sections $(\mathbf{a}-\mathbf{c})$.

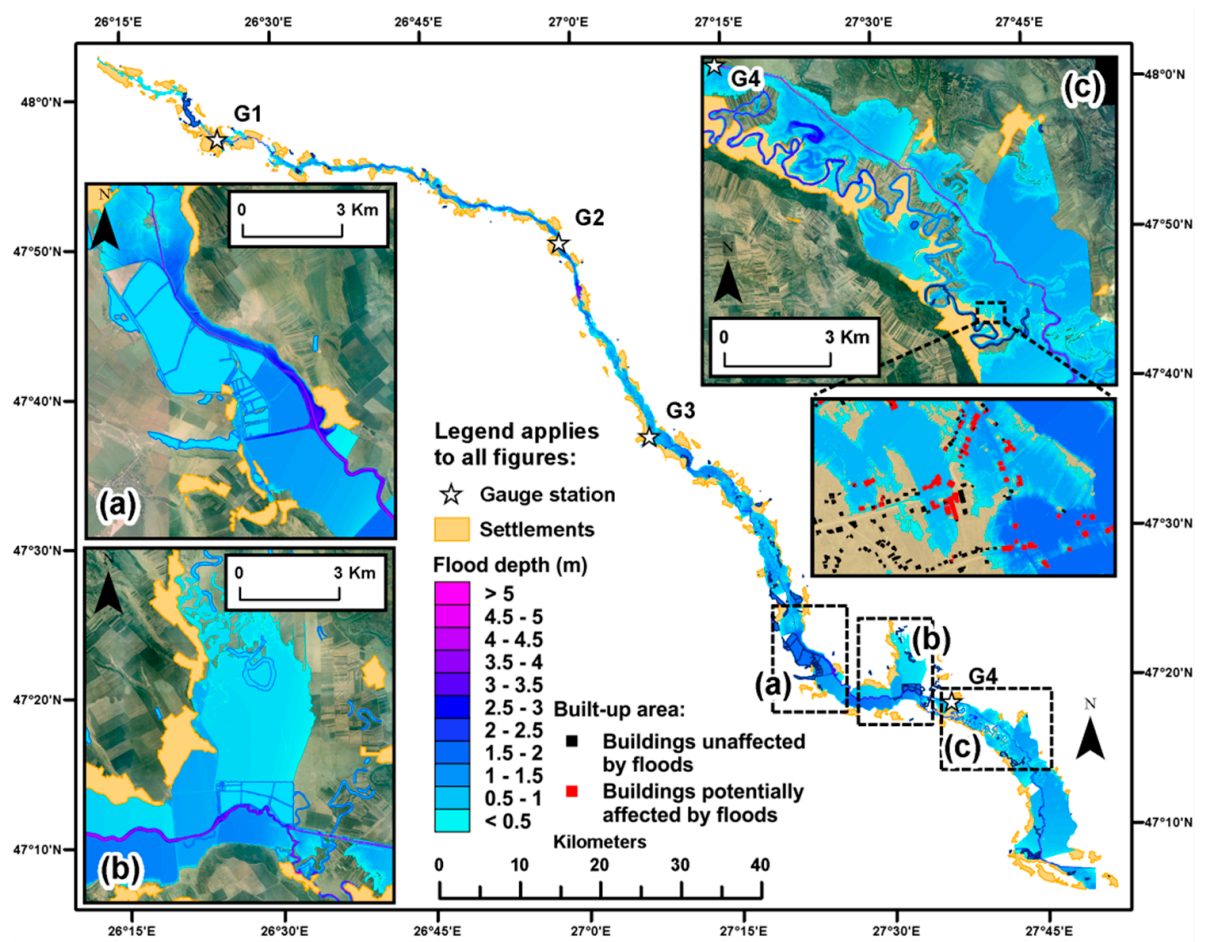

Figure 7. Flood depth derived from 1D HEC-RAS modeling based on LiDAR data (0.5 m spatial resolution) and $Q_{\max } .\left(\mathrm{m}^{3} / \mathrm{s}\right)$ flow rates with $0.1 \%$ (1000-year) recurrence intervals estimated for each gauging station (G1, G2, G3, and G4). The $0.1 \%$ (1000-year) flood depth pattern is highlighted in sections $(\mathbf{a}-\mathbf{c})$. 
Table 3. Number of potentially affected buildings by different flood depth classes (m) computed for each $1 \%$ (100-year) and $0.1 \%$ (1000-year) recurrence interval scenarios using 1 D HEC-RAS modeling.

\begin{tabular}{cccc}
\hline Flood Depth Classes (m) & $\mathbf{1 \%} \mathbf{( 1 0 0 - Y e a r )}$ & $\mathbf{0 . 1} \% \mathbf{~ ( 1 0 0 0 - Y e a r ) ~}$ & ${ }^{\mathbf{1}}$ Diff. \\
\hline$<1.0$ & 2019 & 2832 & 813 \\
$1.0-2.0$ & 41 & 63 & 22 \\
$2.0-3.0$ & 19 & 23 & 4 \\
$3.0-4.0$ & 5 & 9 & 4 \\
$4.0-5.0$ & 0 & 1 & 1
\end{tabular}

${ }^{1}$ Diff.-Differences: the values indicate the increase, from $1 \%$ (100-year) recurrence interval scenario to $0.1 \%$ (1000-year) recurrence interval scenario, of the number of potentially affected buildings by different flood depth classes $(\mathrm{m})$.

\subsubsection{Flood Vulnerability Assessment}

Generally, the flood vulnerability assessment within built-up areas is based on quantifiable variables like flood extent, water velocity, and water depth. This statistical and GIS effort corresponding to the post-processing stage of the 1D HEC-RAS models can provide valuable information regarding the probable damages in cases of hydrological events with possible destructive potential. In this context, because the flood velocity is a constant variable in all 1D computed scenarios $(80 \%$ from the total built-up area are affected by the $0.01-0.25 \mathrm{~m} / \mathrm{s}$ velocity class; $15.5 \%$ from the total built-up area are affected by the $0.25-0.5 \mathrm{~m} / \mathrm{s}$ velocity class; $4 \%$ from the total built-up area are affected by the $0.5-1 \mathrm{~m} / \mathrm{s}$ velocity class), we made the flood vulnerability assessment using only the flood extent and depth variables. Thereby, to generate the flood hazard maps for built-up areas within Jijia floodplain, the water depth corresponding to each flood extent scenario was classified according to MLIT methodology [65], which are based on five flood hazard classes:

- H1-Very low hazard (flood depth $<0.5 \mathrm{~m}$ ): flood does not pose a hazard to people and on-foot evacuation is not difficult.

- $\quad$ H2 - Low hazard (flood depth between $0.5 \mathrm{~m}$ and $1 \mathrm{~m}$ ): flood water poses a hazard for infants and on-foot evacuation of adults becomes difficult; evacuation becomes more complicated.

- H3-Medium hazard (flood depth between $1 \mathrm{~m}$ and $2 \mathrm{~m}$ ): flood depth can cause the drowning of people; but people may be safe inside their homes.

- H4-High hazard (flood depth between $2 \mathrm{~m}$ and $5 \mathrm{~m}$ ): people are exposed to flood hazard even inside their homes and evacuation through the roof is suggested.

- H5-Extreme hazard (flood depth $>5 \mathrm{~m}$ ): built-up structures like single storey houses may get covered by the flood; people may drown, even if they evacuate through the roof of their homes.

According to the $1 \%$ (100-year) recurrence interval scenario, even if the first four hazard classes $(\mathrm{H} 1, \mathrm{H} 2, \mathrm{H} 3$, and $\mathrm{H} 4)$ are encountered, more than $96.8 \%$ of vulnerable buildings are situated in the very low (H1-1406 houses; $67.46 \%$ from total buildings) and low (H2-613 houses; $29.41 \%$ from total buildings) hazard classes. The rest of medium (H3) and high (H4) hazard classes could affect approximately 65 buildings (H3-1.96\% from total buildings; H4-1.15\% from total buildings) (Figure 8). In the case of the $0.1 \%$ (1000-year) recurrence intervals scenario, $56.61 \%$ of total vulnerable buildings are potentially very minorly affected by floods (H1-1658 buildings), $40.09 \%$ of total vulnerable buildings are potentially minorly affected by floods ( $\mathrm{H} 2-1174$ buildings); the remaining $3.3 \%$ are located in the medium (H3-63 buildings) or high (H4-33 buildings) exposed area to flood hazard (Figure 9). Overall, the significant difference between flood hazard maps generated based on 1\% (100-year) (Figure $8 \mathrm{a}-\mathrm{c}$ ) and $0.1 \%$ (1000-year) (Figure $9 \mathrm{a}-\mathrm{c}$ ) recurrence interval scenarios are only observed in the case of the $\mathrm{H} 2$ class. The increasing number of potentially low affected buildings by floods according to the $0.1 \%$ (1000-year) recurrence interval scenario is induced by morphological features and habitation practice within the Jijia floodplain (e.g., settlements located on the first flooded terraces) (Table 4). 


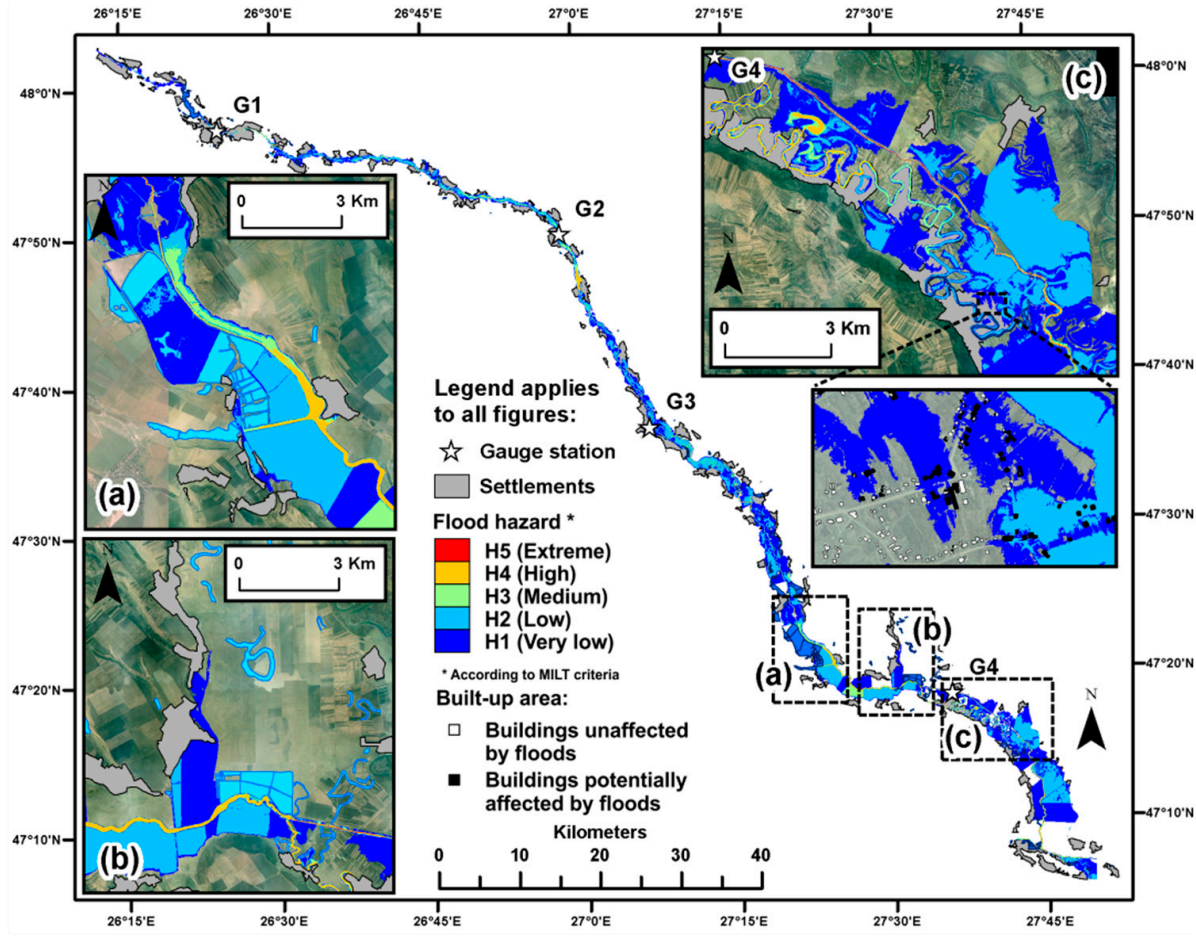

Figure 8. Flood hazard pattern based on flood depth classification according to the MILT criteria. Data derived from 1D HEC-RAS modeling based on LiDAR data $\left(0.5 \mathrm{~m}\right.$ spatial resolution) and $Q_{\max }\left(\mathrm{m}^{3} / \mathrm{s}\right)$ flow rates with 1\% (100-year) recurrence interval estimated for each gauging station (G1, G2, G3 and G4). The 1\% (100-year) flood hazard pattern is highlighted for sections (a-c).

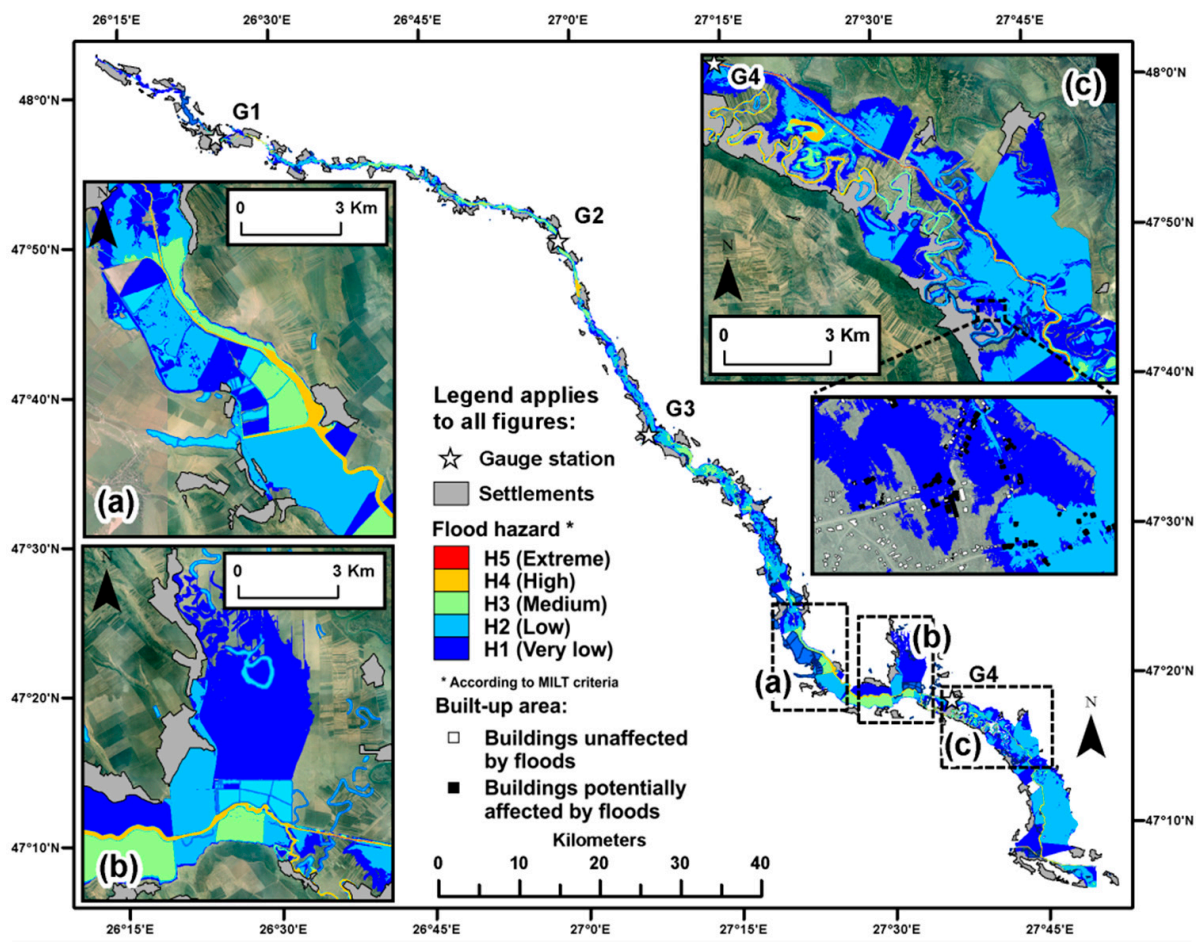

Figure 9. Flood hazard pattern based on flood depth classification according to the MILT criteria. Data derived from 1D HEC-RAS modeling based on LiDAR data $\left(0.5 \mathrm{~m}\right.$ spatial resolution) and $Q_{\max }\left(\mathrm{m}^{3} / \mathrm{s}\right)$ flow rates with $0.1 \%$ (1000-year) recurrence interval estimated for each gauging station (G1, G2, G3, and G4). The $0.1 \%$ (1000-year) flood hazard pattern is highlighted for sections (a-c). 
Table 4. Number of potentially affected buildings by floods vs. flood hazard classes computed for each $1 \%$ (100-year) and 0.1\% (1000-year) recurrence interval scenarios using 1D HEC-RAS modeling.

\begin{tabular}{|c|c|c|c|}
\hline Flood Hazard Classes ${ }^{1}$ & 1\% (100-Year) & $0.1 \%$ (1000-Year) & ${ }^{2}$ Diff. \\
\hline H1 (Very low) & 1406 & 1658 & 252 \\
\hline H2 (Low) & 613 & 1174 & 561 \\
\hline H3 (Medium) & 41 & 63 & 22 \\
\hline H4 (High) & 24 & 33 & 9 \\
\hline
\end{tabular}

${ }^{1}$ Flood hazard classes according to MLIT criteria [65] where the H5 (Extreme) flood hazard class was excluded because no buildings potentially affected by floods with depths greater than $5 \mathrm{~m}$ were recorded; ${ }^{2}$ Diff.-Differences: the values indicate the increase, from $1 \%$ (100-year) recurrence interval scenario to $0.1 \%$ (1000-year) recurrence interval scenario, of the number of potentially affected buildings by different flood hazard classes.

\subsection{Differences between 1D HEC-RAS Models and Official Flood Hazard Maps}

Following the main objective of this approach, we managed to compare the flood hazard maps we obtained for $1 \%$ (100-year) and $0.1 \%$ (1000-year) recurrence intervals with official flood hazards maps [66] realized by specialists of NARW for the same recurrence intervals under the first stage of Flood Directive 2007/60/EC implementation in Romania [17-19]. The comparisons take into consideration the following indicators for each recurrence interval scenario: flood extent (Figures 10 and 11), total number of potentially affected buildings (Table 5 ), and the flood hazard classification based on water depth according to MLIT criteria (Figure 12) [65].

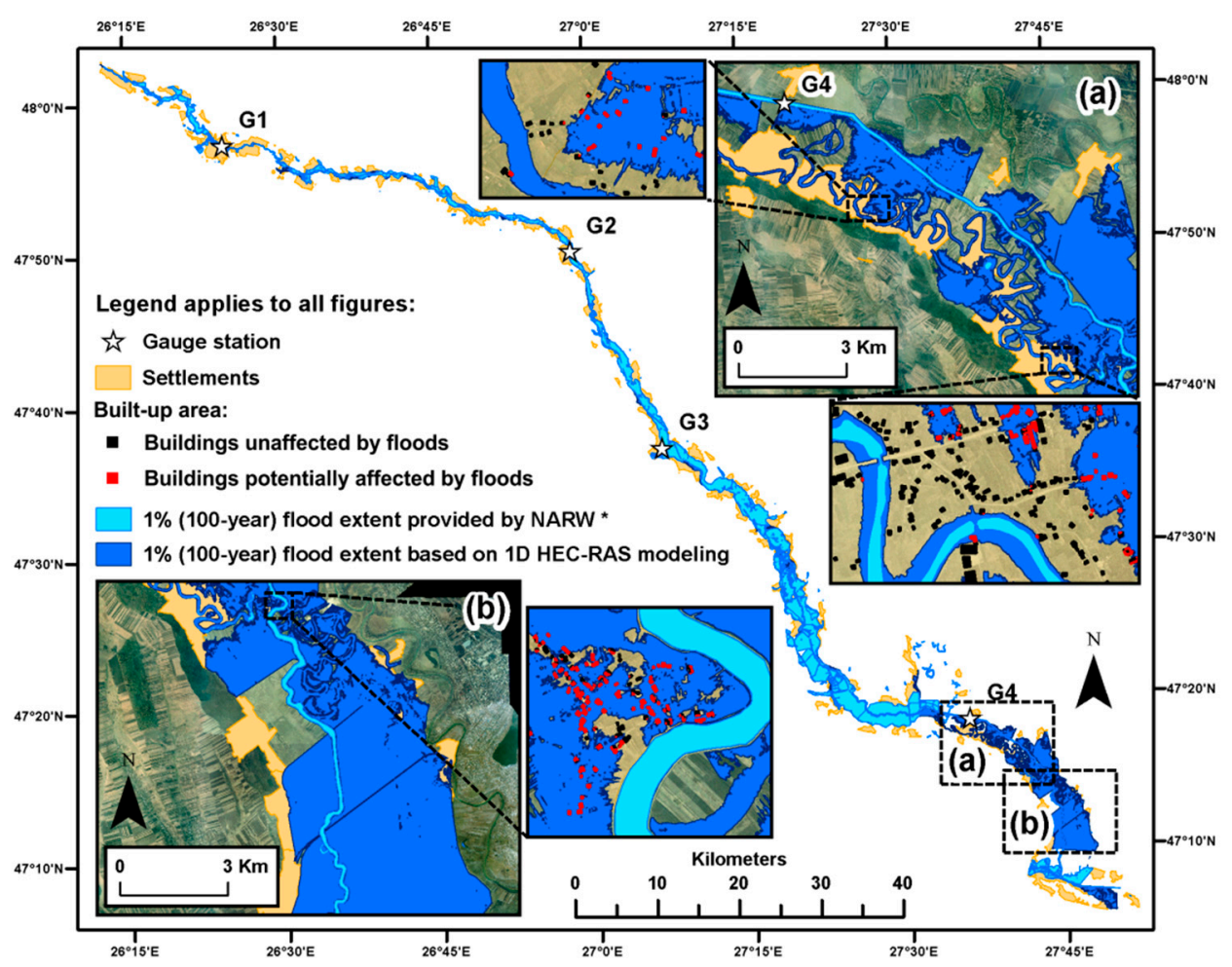

Figure 10. Comparison between official flood extent provided by NARW for 1\% (100-year) recurrence interval probability and 1D HEC-RAS flood extent for 1\% (100-year) recurrence interval probability. The significant differences recorded within the lower sector of the Jijia floodplain are highlighted for sections $(\mathbf{a}, \mathbf{b})$. 


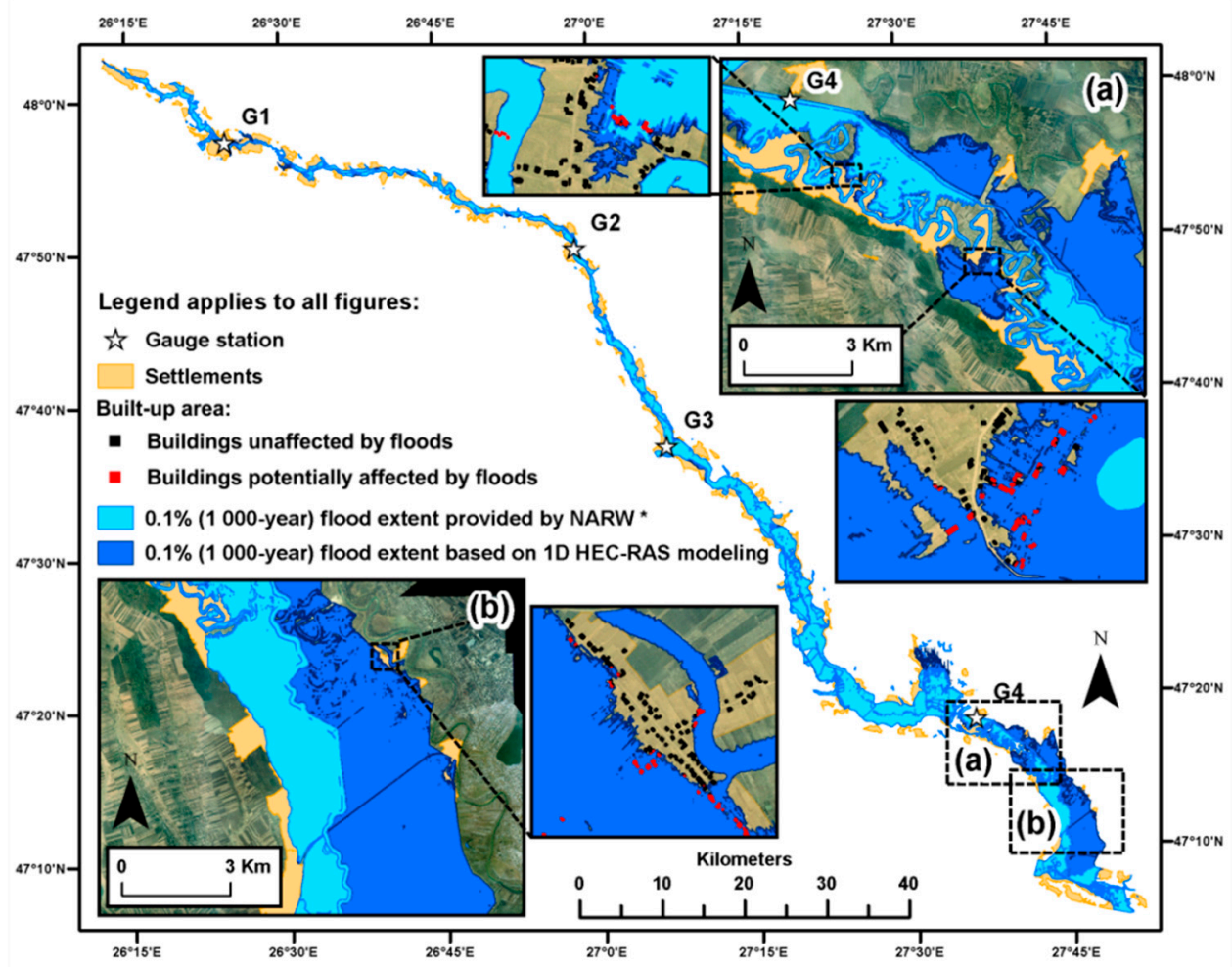

Figure 11. Comparison between official flood extent provided by NARW for the $0.1 \%$ (1000-year) recurrence interval probability and 1D HEC-RAS flood extent for the $0.1 \%$ (1000-year) recurrence interval probability. The significant differences recorded within the lower sector of the Jijia floodplain are highlighted for sections $(\mathbf{a}, \mathbf{b})$.

Table 5. Comparison between flood extent and total number of buildings potentially affected by floods based on NARW flood hazard maps and 1D HEC-RAS scenarios computed for $1 \%$ (100-year) and $0.1 \%$ (1000-year) recurrence intervals.

\begin{tabular}{|c|c|c|c|c|c|c|}
\hline \multirow{2}{*}{$\begin{array}{l}\text { Recurrence } \\
\text { Interval }\end{array}$} & \multicolumn{2}{|c|}{ Flood Extent $\left(\mathbf{k m}^{2}\right)$} & \multirow{2}{*}{${ }^{4}$ Diff. } & \multicolumn{2}{|c|}{$\begin{array}{l}\text { Number of Buildings } \\
\text { Potentially Affected by Floods }\end{array}$} & \multirow{2}{*}{${ }^{5}$ Diff. } \\
\hline & $\begin{array}{l}{ }^{3} \text { NARW Flood } \\
\text { Hazard Maps }\end{array}$ & $\begin{array}{l}\text { 1D HEC-RAS } \\
\text { Models }\end{array}$ & & $\begin{array}{l}3 \text { NARW Flood } \\
\text { Hazard Maps }\end{array}$ & $\begin{array}{l}\text { 1D HEC-RAS } \\
\text { Models }\end{array}$ & \\
\hline $11 \%$ & 145.23 & 195.92 & -50.69 & 830 & 2084 & -1254 \\
\hline${ }^{2} 0.1 \%$ & 226.65 & 251.82 & -25.17 & 2617 & 2928 & -311 \\
\hline
\end{tabular}

${ }^{1}$ 100-year recurrence interval probability; ${ }^{2}$ 1000-year recurrence interval probability; ${ }^{3}$ NARW-National Administration "Romanian Waters" flood hazard maps; ${ }^{4}$ Diff.-Differences: the negative values indicate an underestimation of flood extent within the Jijia floodplain provided by NARW hazard maps compared to 1D HEC-RAS scenarios; ${ }^{5}$ Diff.-Differences: the negative values indicate an underestimation of the number of buildings potentially affected by floods within the Jijia floodplain provided by NARW hazard maps compared to 1D HEC-RAS scenarios.

According to flood extent maps provided by NARW for the 1\% (100-year) recurrence interval within the Jijia floodplain, a surface of $145.23 \mathrm{~km}^{2}$ and 830 buildings (e.g., houses, attachment buildings, administrative buildings) will potentially be affected by floods. Comparing the official data with 1D HEC-RAS flood extent patterns for the $1 \%$ (100-year) recurrence interval, a significant difference is observed (Figure 10a,b). Therefore, $50.69 \mathrm{~km}^{2}$ of flood extent and 1254 buildings potentially affected by floods were removed from flood risk areas by the official scenarios (Table 5). Also, a significant difference is noted in the case of the flood maps generated by NARW for the $0.1 \%$ (1000-year) recurrence interval characterized by $226.65 \mathrm{~km}^{2}$ of total flood extent and 2617 buildings potentially affected by floods (Figure 11a,b). Compared to 1D HEC-RAS 0.1\% (1000-year) results, more than $25.17 \mathrm{~km}^{2}$ of 
potentially flooded area and 311 buildings potentially affected by floods within the Jijia floodplain were underestimated by the NARW flood scenarios (Table 5).
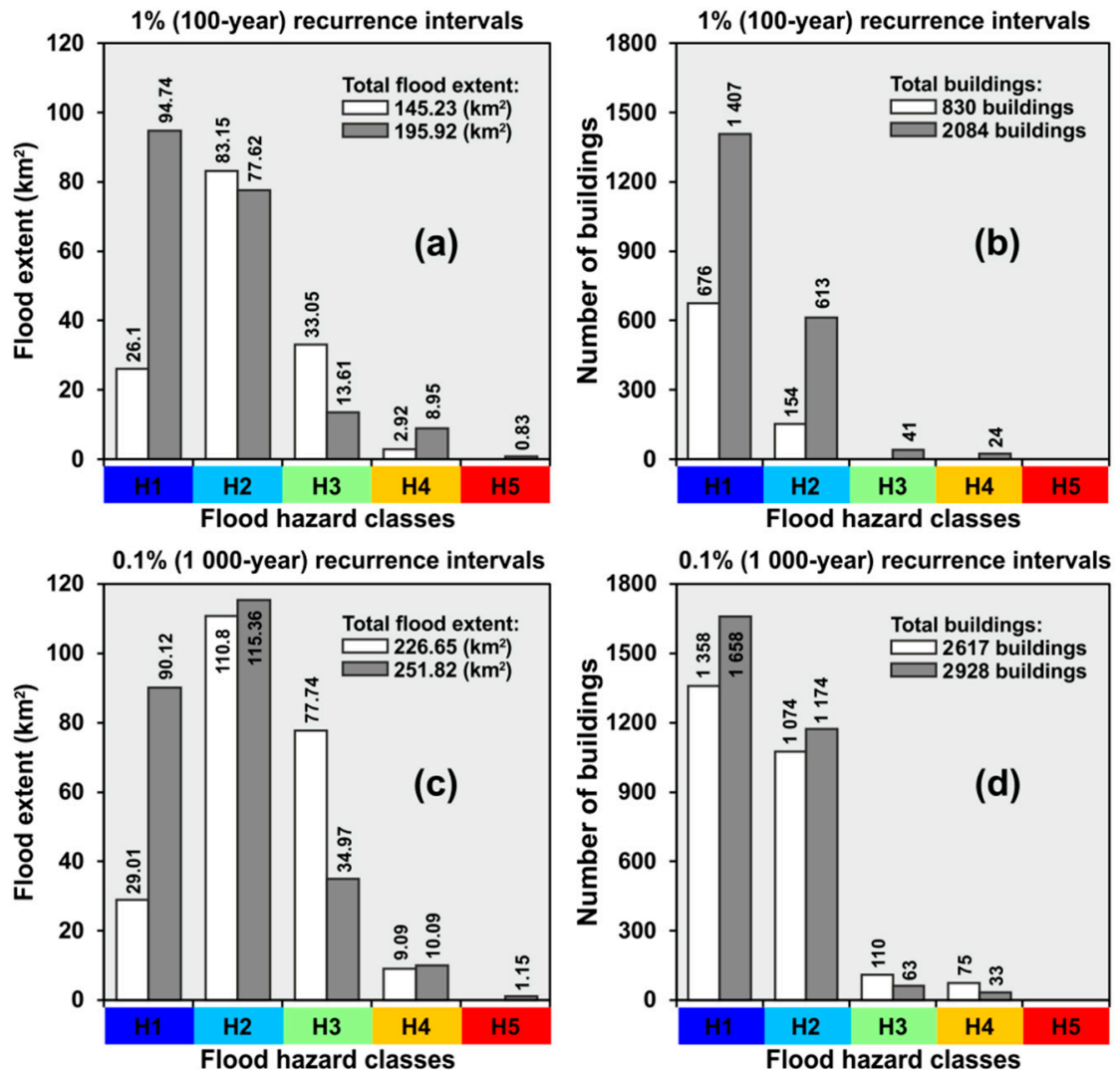

Legend applies for all figures:

$\square$ NARW flood hazard maps $\square$ 1D HEC-RAS models

Figure 12. Comparison between official flood hazard maps provided by NARW and the maps generated based on 1D HEC-RAS modeling: (a) flood extent area vs. flood hazard classes computed for 1\% (100-year) recurrence intervals, (b) number of buildings potentially affected by floods vs. flood hazard classes computed for 1\% (100-year) recurrence intervals, (c) flood extent area vs. flood hazard classes computed for $0.1 \%$ (1000-year) recurrence intervals, and (d) number of buildings potentially affected by floods vs. flood hazard classes computed for $0.1 \%$ (1000-year) recurrence intervals.

Using flood hazard classification based on water depth according to MLIT criteria, high differences between official hazard maps and 1D HEC-RAS models were also observed (Figure 12). According to flood extent area vs. flood hazard classes computed for $1 \%$ (100-year) recurrence intervals, a significant difference was recorded in the case of $\mathrm{H} 1$ (flood depth $<0.5 \mathrm{~m}$ ), where official flood hazard maps underestimate $68.64 \mathrm{~km}^{2}$ of vulnerable area, and $\mathrm{H} 3$ (flood depth between 1-2 m), where official flood hazard maps overestimate $19.44 \mathrm{~km}^{2}$ of vulnerable area (Figure 12a). In this context, the flood extents influence the estimation of the number of buildings potentially affected by floods vs. flood hazard classes computed for 1\% (100-year) recurrence intervals. Thereby, the most significant differences were recorded in the case of $\mathrm{H} 1$ (flood depth $<0.5 \mathrm{~m}$ ), where official flood hazard maps do not take into account 731 potentially affected buildings by floods, and H2 (flood depth between $0.5-1 \mathrm{~m}$ ), where official flood hazard maps exclude 459 such buildings (Figure 12b).

Similar differences were also noted in the case of flood extent area vs. flood hazard classes computed for $0.1 \%$ (1000-year) recurrence intervals. Comparing the official flood extent with 1D HEC-RAS flood extent, which were both computed for $0.1 \%$ (1000-year) recurrence intervals, significant differences were recorded in the case of $\mathrm{H} 1$ (flood depth $<0.5 \mathrm{~m}$ ), where official data underestimated $61.11 \mathrm{~km}^{2}$ of vulnerable area, and H3 (flood depth between 1-2 m), where official flood hazard maps overestimated 
$42.5 \mathrm{~km}^{2}$ of vulnerable area (Figure 12c). Following the same trend, the number of buildings potentially affected by floods vs. flood hazard classes computed for $0.1 \%$ (1000-year) recurrence intervals recorded difference in the case of $\mathrm{H} 1$ (flood depth $<0.5 \mathrm{~m}$ ), where official flood hazard maps do not take into account 300 potentially affected buildings, and $\mathrm{H} 2$ (flood depth between $0.5-1 \mathrm{~m}$ ), where official flood hazard maps exclude 100 potentially affected buildings (Figure 12d).

The approach and results of our study lead to the claim that the 1D hydraulic modeling using HEC-RAS 5.0.7 and high-density LiDAR data applied for flood simulation generates sufficiently accurate information regarding flood hazard and vulnerability. As specific hydraulic modeling applications continue to improve and the availability of hydrological data (e.g., flow rate, water level) and DEM resolution increases (e.g., LiDAR data), more GIS data needs to be integrated and used in flood modeling. In this framework, 1D flood simulations based on LiDAR derived DEM provide the best results within floodplain areas. Due to its accurate representation of the complex hydraulic conditions that can be found in floodplains (e.g., channels, confluences, reservoirs, ponds, polders), 1D hydraulic models can capture the hydraulic behavior of the river (e.g., water propagation, flood extent and velocity, flood depth) in a more accurate way than other methods, except for the urban area where flood movements are at least fully 2D.

Despite all these benefits, there are limitations to 1D HEC-RAS modeling for flood hazard assessment which depend on the detail of input data, area characteristics, level of complexity in the output data, project time, and money etc. Its use for large-scale analysis (e.g., large river basin) has to be done with caution because the $1 \mathrm{D}$ modeling processing consumes many resources (time and money) and the results can understate flood risk perception.

However, due to the adaptability of the 1D HEC-RAS modeling in a computationally efficient manner over complex topography, this method is essential for the delineation of flood prone areas on a medium and large scale in the context of climate change trends and development pressure.

Noteworthy is the fact that even in a well-planned area like the Jijia floodplain, flood hazard can be a constant threat to human society. Several examples can be invoked when flash flood induced by heavy rains or accidental discharge caused by human error turn into a catastrophic flood event on this territory [8]. In the same framework, by comparing the 1D HEC-RAS modeling results (e.g., flood extent, total number of potentially affected buildings, flood hazard classification based on water depth) with the existent official flood hazard maps previously drawn for Romania, we highlight the effects of 1D cross-sections accuracy generated based on LiDAR-derived DEM in the delineation of flood prone areas and hazard assessment.

\section{Conclusions}

Floods and associated hazards have become a topic of growing concern for citizens, authorities, and policy-makers within affected territories, especially in the highly populated floodplains. For this reason, the ability to generate flood hazard maps based on new computer algorithms and hydraulic modeling software and integrate the results (e.g., GIS database) within the regional management plans and/or local studies are important aspects of flood mitigation.

In the present study, flood hazard and vulnerability were assessed using the 1D HEC-RAS hydraulic modeling and LiDAR derivate DEM with $0.5 \mathrm{~m}$ spatial resolutions within the Jijia floodplain. Based on multi-scenario development using the estimated discharge data for 1\% (100-year) and 0.1\% (1000-year) recurrence intervals probabilities at a four gauge station (G1: Dorohoi-50 year monitoring period, G2: Dangeni-49 year monitoring period, G2 Todireni-49 year monitoring period and G4: Victoria-63 year monitoring period), the results led to the formulation of the following concluding remarks:

- According to the 1D HEC-RAS flood scenario with a 1\% (100-year) recurrence interval probability, $61.11 \%\left(195.92 \mathrm{~km}^{2}\right)$ of Jijia floodplain and 2084 buildings are potentially affected by floods. Based on MILT criteria for flood hazard classification, 1406 buildings are located within H1 area, 
613 buildings are located within $\mathrm{H} 2$ area, 41 buildings are located within $\mathrm{H} 3$, and 24 buildings are located within $\mathrm{H} 4$.

- According to the 1D HEC-RAS flood scenario with a $0.1 \%$ (1000-year) recurrence interval probability, $78.54 \%$ ( $\left.251.82 \mathrm{~km}^{2}\right)$ of Jijia floodplain and 2928 buildings are potentially affected by floods. Using the same MILT criteria for flood hazard classification, 1658 buildings are located within $\mathrm{H} 1$ area, 1174 buildings are located within $\mathrm{H} 2$ area, 53 buildings are located within $\mathrm{H} 3$, and 33 buildings are located within $\mathrm{H} 4$ area.

- Comparing the flood hazard maps generated using the 1D HEC-RAS modeling with the official flood hazard maps provided by NARW, 1254 buildings according to the $1 \%$ (100-year) recurrence interval scenario and 311 buildings according to the $0.1 \%$ (1000-year) recurrence interval scenario were removed from flood risk areas by the official data. Thereby, this difference indicates that the NARW flood scenarios underestimate the flood impact within the Jijia floodplain.

- The results obtained in this study improve the accuracy of official flood hazard maps and contribute to small-scale delineation of flood patterns with $1 \%$ (100-year) and $0.1 \%$ (1000-year) recurrence intervals in the Jijia floodplain.

Overall, the application of 1D HEC-RAS hydraulic modeling based on LiDAR derived DEM with high resolution can answer real questions regarding flood hazard at a regional level. Developing flood scenarios for different recurrence intervals on a small-scale is a very important aspect for any flood mitigation effort, especially in rural areas where the hydrological disasters are a major contributor to material losses and trauma population.

Author Contributions: Conceptualization, E.H., A.M.-P., A.U., L.E.P., C.C.S., and A.G.; methodology, E.H., A.M.-P. and A.U.; software, E.H. and A.U.; validation, A.M.-P. and A.G.; formal analysis, E.H. and A.M.-P.; investigation, E.H. and A.M.-P.; resources, E.H., A.M.-P., and L.E.P.; data curation, A.M.-P., C.C.S., and A.G.; writing-original draft preparation, E.H. and A.M.-P.; visualization, E.H., A.M.-P., C.C.S., and A.G.; supervision, A.M.-P. and A.G.; project administration, A.M.-P.; funding acquisition, A.M.-P. and A.G. All authors have read and agreed to the published version of the manuscript.

Funding: This work was co-funded by the Department of Geography, Faculty of Geography and Geology, Alexandru Ioan Cuza University of Iaşi (UAIC), and by the Ministry of Research and Innovation of Romania within Program 1-Development of the national RD system, Subprogram 1.2-Institutional Performance-RDI excellence funding projects, Contract no.34PFE/19.10.2018 (beneficiary: UAIC).

Acknowledgments: The authors would like to express their gratitude to the employees of the Romanian Waters Agency Bucharest, Prut-Bîrlad Water Administration Iaşi, particularly to Claudiu Pricop, hydrologist at this research and administration agency, who kindly provided a significant part of the LiDAR data used in the present study. All data were processed in both the Geomatics Laboratory of Doctoral School of Geoscience, Department of Geography, Faculty of Geography and Geology, Alexandru Ioan Cuza University of Iaşi (UAIC) and the Geoarchaeology Laboratory (Coordinator: A.M.-P.) of the Institute for Interdisciplinary Research, Science Research Department, "Alexandru Ioan Cuza" University of Iaşi (UAIC), Romania. Our thanks go to all the anonymous reviewers who helped us in improving the manuscript.

Conflicts of Interest: The authors declare no conflict of interest. The founding sponsors had no role in the design of the study; in the collection, analyses, or interpretation of data; in the writing of the manuscript, and in the decision to publish the results.

\section{Abbreviations}

The following abbreviations are used in this manuscript:

$\begin{array}{ll}\text { LiDAR } & \text { Light Detection and Ranging } \\ \text { DEM's } & \text { Digital Elevation Models } \\ \text { GIS } & \text { Geographic Information System } \\ \text { HEC-RAS } & \text { Hydrologic Engineering Canter's-River Analysis System } \\ \text { 1D, 2D } & \text { HEC-RAS one dimension, HEC-RAS two dimension } \\ \text { MIKE SHE } & \text { Hydrological modeling system for simulating surface water flow } \\ \text { NARW } & \text { National Administration "Romanian Waters" } \\ \text { UAIC } & \text { University "Alexandru Ioan Cuza" of Iaşi } \\ \text { LISFLOOD-FP } & \text { Two-dimensional hydrodynamic model research tool }\end{array}$




$\begin{array}{ll}\text { USACE HEC } & \text { U.S. Army Corps of Engineers Hydrologic Engineering Center } \\ \text { PBWA } & \text { Prut-Bîrlad Water Administration } \\ \mathrm{G}_{1} & \text { Gauging station-Dorohoi } \\ \mathrm{G}_{2} & \text { Gauging station-Dangeni } \\ \mathrm{G}_{3} & \text { Gauging station-Todireni } \\ \mathrm{G}_{4} & \text { Gauging station-Victoria } \\ \text { CLMS } & \text { Copernicus Land Monitoring Service } \\ \text { CLC } & \text { Corine Land Cover } \\ \text { RR } & \text { Mike 11 Rainfall-runoff } \\ \mathrm{HD} & \text { Mike 11 Hydrodynamics } \\ \text { MLIT } & \text { Ministry of Land Infrastructure and Transport (Japan) } \\ \mathrm{H} 1 & \text { Very low hazard according to MLTI classification } \\ \mathrm{H} 2 & \text { Low hazard according to MLTI classification } \\ \mathrm{H} 3 & \text { Medium hazard according to MLTI classification } \\ \mathrm{H} 4 & \text { High hazard according to MLTI classification } \\ \mathrm{H} 5 & \text { Extreme hazard according to MLTI classification }\end{array}$

\section{References}

1. Alfieri, L.; Pappenberger, F.; Wetterhall, F.; Haiden, T.; Richardson, D.; Salamon, P. Evaluation of ensemble streamflow predictions in Europe. J. Hydrol. 2014, 517, 913-922. [CrossRef]

2. Hall, J.; Arheimer, B.; Borga, M.; Brazdil, R.; Claps, P.; Kiss, A.; Kjeldsen, T.R.; Kriauciuniene, J.; Kundzewicz, Z.W.; Lang, M.; et al. Understanding flood regime changes in Europe: A state-of-the-art assessment. Hydrol. Earth Syst. Sci. 2014, 18, 2735-2772. [CrossRef]

3. Hall, J.; Arheimer, B.; Aronica, G.T.; Bilibashi, A.; Boháč, M.; Bonacci, O.; Borga, M.; Burlando, P.; Castellarin, A.; Chirico, G.B.; et al. A European Flood Database: Facilitating comprehensive flood research beyond administrative boundaries. Proc. IAHS 2015, 370, 89-95. [CrossRef]

4. Blöschl, G.; Hall, J.; Parajka, J.; Perdigão, R.A.P.; Merz, B.; Arheimer, B.; Aronica, G.T.; Bilibashi, A.; Bonacci, O.; Borga, M.; et al. Changing climate shifts timing of European floods. Science 2017, 357, 588-590. [CrossRef] [PubMed]

5. Kundzewicz, Z.W.; Pinskwar, I.; Brakenridge, G.R. Large floods in Europe, 1985-2009. Hydrol. Sci. J. 2013, 58, 1-7. [CrossRef]

6. Schneider, C.; Laize, C.L.R.; Acreman, M.C.; Flörke, M. How will climate change modify river flow regimes in Europe? Hydrol. Earth Syst. Sci. 2013, 17, 325-339. [CrossRef]

7. Urzica, A.; Mihu-Pintilie, A.; Huţanu, E.; Ghindaoanu, V.B.; Albu, L.M. Using GIS methods for modeling exceptional flood events in Baseu river basin, NE Romania. In Proceedings of the 4th International Scientific Conference Geobalcanica 2018, Ohrid, North Macedonia, 15-16 May 2018; Volume 4, pp. 463-471. [CrossRef]

8. Romanescu, G.; Cîmpianu, C.I.; Mihu-Pintilie, A.; Stoleriu, C.C. Historic flood events in NE Romania (post-1990). J. Maps 2017, 13, 787-798. [CrossRef]

9. Mihu-Pintilie, A.; Cîmpianu, C.I.; Stoleriu, C.C.; Pérez, M.N.; Paveluc, L.E. Using High-Density LiDAR Data and 2D Streamflow Hydraulic Modeling to Improve Urban Flood Hazard Maps: A HEC-RAS Multi-Scenario Approach. Water 2019, 11, 1832. [CrossRef]

10. Romanescu, G.; Stoleriu, C.C. Exceptional floods in the Prut basin, Romania, in the context of heavy rains in the summer of 2010. Nat. Hazards Earth Syst. Sci. 2017, 17, 381-396. [CrossRef]

11. Romanescu, G.; Mihu-Pintilie, A.; Stoleriu, C.C.; Carboni, D.; Paveluc, L.; Cîmpianu, C.I. A Comparative Analysis of Exceptional Flood Events in the Context of Heavy Rains in the Summer of 2010: Siret Basin (NE Romania) Case Study. Water 2018, 10, 216. [CrossRef]

12. Stoleriu, C.C.; Urzica, A.; Mihu-Pintilie, A. Improving flood risk map accuracy using high-density LiDAR data and the HEC-RAS river analysis system: A case study from north-eastern Romania. J. Flood Risk Manag. 2019, e12572. [CrossRef]

13. Romanescu, G.; Stoleriu, C.C. An inter-basin backwater overflows (the Buhai Brook and the Ezer reservoir on the Jijia River, Romania). Hydrol. Process. 2013, 28, 3118-3131. [CrossRef] 
14. Cîmpianu, C.I.; Mihu-Pintilie, A. Mapping Floods Using Open Source Data and Software-Sentinel-1 and ESA Snap. In Proceedings of the 4th International Scientific Conference Geobalcanica 2018, Ohrid, North Macedonia, 15-16 May 2018; Volume 4, pp. 521-529. [CrossRef]

15. Huţanu, E.; Mihu-Pintilie, A.; Urzica, A.; Albu, L.M.; Ghindaoanu, V.B. The use of GIS techniques for obtaining potentially floodable surfaces in the Jijia floodplain. In Proceedings of the 4th International Scientific Conference Geobalcanica 2018, Ohrid, North Macedonia, 15-16 May 2018; Volume 4, pp. 473-480. [CrossRef]

16. Mihu-Pintilie, A.; Nicu, I.C. GIS-based Landform Classification of Eneolithic Archaeological Sites in the Plateau-plain Transition Zone (NE Romania): Habitation Practices vs. Flood Hazard Perception. Remote Sens. 2019, 11, 915. [CrossRef]

17. EC (European Commission). Directive 2007/60/EC of the European Parliament and of the Council of 23 October 2007 on the assessment and management of flood risks. In Official Journal of the European Union; Office for Official Publications of the European Communities: Luxembourg, 2007; Volume L288, pp. 27-34. Available online: http://eur-lex.europa.eu/legal-content/EN/TXT/?uri=CELEX:32007L0060 (accessed on 4 March 2020).

18. Priest, S.J.; Suykens, C.; Van Rijswick, H.F.M.W.; Schellenberger, T.; Goytia, S.B.; Kundzewicz, Z.W.; Van Doorn-Hoekveld, W.J.; Beyers, J.-C.; Homewood, S. The European Union approach to flood risk management and improving societal resilience: Lessons from the implementation of the Floods Directive in six European countries. Ecol. Soc. 2016, 21, 50. [CrossRef]

19. Romanescu, G.; Stoleriu, C.C.; Mihu-Pintilie, A. Implementation of EU Water Framework Directive (2000/60/EC) in Romania-European Qualitative Requirements. In Water Resources Management in Romania; Negm, A., Romanescu, G., Zeleňáková, M., Eds.; Springer: Cham, Switzerland, 2020; pp. 17-55. [CrossRef]

20. Papaioannou, G.; Varlas, G.; Terti, G.; Papadopoulos, A.; Loukas, A.; Panagopoulos, Y.; Dimitriou, E. Flood Inundation Mapping at Ungauged Basins Using Coupled Hydrometeorological-Hydraulic Modelling: The Catastrophic Case of the 2006 Flash Flood in Volos City, Greece. Water 2019, 11, 2328. [CrossRef]

21. Haghizadeh, A.; Siahkamari, S.; Zeinivand, H.; Tahmasebipour, N.; Rhamti, O. Spatial prediction of flood-susceptible areas using frequency ratio and maximum entropy models. Geocarto Int. 2017, 33, 927-941. [CrossRef]

22. Huţanu, E.; Urzica, A.; Paveluc, L.E.; Stoleriu, C.C.; Grozavu, A. The role of hydro-technical works in diminishing flooded areas. Case study: The June 1985 flood on the Miletin River. In Proceedings of the 16th International Conference on Environmental Science and Technology (CEST2019), Rhodes, Greece, 4-7 September 2019. Available online: https://cest2019.gnest.org/conference-program (accessed on 7 April 2020).

23. Sosa, J.; Sampson, C.; Smith, A.; Neal, J.; Bates, P. A toolbox to quickly prepare flood inundation models for LISFLOOD-FP simulations. Environ. Model. Softw. 2020, 123, 104561. [CrossRef]

24. Wing, O.E.J.; Bates, P.D.; Neal, J.C.; Sampson, C.C.; Smith, A.M.; Quinn, N.; Shustikova, I.; Domeneghetti, A.; Gilles, D.W.; Goska, R.; et al. A New Automated Method for Improved Flood Defense Representation in Large-Scale Hydraulic Models. Water Resour. Res. 2019, 55, 11007-11034. [CrossRef]

25. Bizhanimanzar, M.; Leconte, R.; Nuth, M. Catchment-Scale Integrated Surface Water-Groundwater Hydrologic Modelling Using Conceptual and Physically Based Models: A Model Comparison Study. Water 2020, 12, 363. [CrossRef]

26. Hu, D.; Lu, C.; Yao, S.; Yuan, S.; Zhu, Y.; Duan, C.; Liu, Y. A prediction-correction solver for real-time simulation of free-Surface flow in river networks. Water 2019, 11, 2525. [CrossRef]

27. Abdelkarim, A.; Gaber, A.F. Flood risk assessment of the Wadi Nu'man basin, Mecca, Saudi Arabia (during the period, 1988-2019) based on the integration of Geomatics and hydraulic modeling: A case study. Water 2019, 11, 1887. [CrossRef]

28. Thanh, D.; De Smedt, F. A combined hydrological and hydraulic model for flood prediction in Vietnam applied to the Huong river basin as a test case study. Water 2017, 9, 879. [CrossRef]

29. Vojtec, M.; Petroselli, A.; Vojteková, J.; Asgharinia, S. Flood inundation mapping in small and ungauged basins: Sensitivity analysis using the EBA4SUB and HEC-RAS modeling approach. Hydrol. Res. 2019, 50, 1002-1019. [CrossRef]

30. Bures, L.; Roub, R.; Sychova, P.; Gdulova, K.; Doubalova, J. Comparison of bathymetric data sources used in hydraulic modeling of flood. J. Flood Risk Manag. 2019, 12 (Suppl. 1), e12495. [CrossRef] 
31. Dey, S.; Saksena, S.; Merwade, V. Assessing the effect of different bathymetric models on hydraulic simulation of rivers in data sparse regions. J. Hydrol. 2019, 575, 838-851. [CrossRef]

32. U.S. Army Corps of Engineers Hydrologic Engineering Center. HEC-RAS 5.0-User's Manual. Available online: https://www.hec.usace.army.mil/software/hec-ras/documentation/HEC-RASUsers\%20Manual.pdf (accessed on 4 March 2020).

33. Frank, E.; Ostan, A.; Coccato, M.; Stelling, G.S. Use of An Integrated One Dimensional-two Dimensional Hydraulic Modelling Approach for Flood Hazard and Risk Mapping. WIT Trans. Ecol. Environ. 2001, 50, 99-108. [CrossRef]

34. Song, Y.; Park, Y.; Lee, J.; Park, M.; Song, Y. Flood forecasting and warning system structures: Procedure and application to a small urban stream in South Korea. Water 2019, 11, 1571. [CrossRef]

35. Pasquier, U.; He, Y.; Hooton, S.; Goulden, M.; Hiscock, K.M. An integrated 1D-2D hydraulic modeling approach to assess the sensitivity of a coastal region to compound flooding hazard under climate change. Nat. Hazards 2018, 94, 1-23. [CrossRef]

36. Patel, D.P.; Ramirez, J.A.; Srivastava, P.K.; Bray, M.; Han, D. Assessment of flood inundation mapping of Surat city by coupled 1D/2D hydrodynamic modeling: A case application of the new HEC-RAS 5. Nat. Hazards 2017, 89, 93-130. [CrossRef]

37. Urzica, A.; Huţanu, E.; Mihu-Pintilie, A.; Stoleriu, C.C. Dam breaks analysis using HEC-RAS techniques. Case study: Cal Alb dam (NE Romania). In Proceedings of the 16th International Conference on Environmental Science and Technology (CEST2019), Rhodes, Greece, 4-7 September 2019. Available online: https://cest2019.gnest.org/conference-program (accessed on 7 April 2020).

38. Enea, A.; Urzica, A.; Breabăn, I.G. Remote sensing, GIS and HEC-RAS techniques, applied for flood extent validation, based on Landsat imagery, LiDAR and hydrological data. Case study: Baseu River, Romania. J. Environ. Prot. Ecol. 2018, 19, 1091-1101.

39. Huţanu, E.; Urzica, A.; Paveluc, L.E.; Stoleriu, C.C.; Grozavu, A. Comparative analysis of flooded areas using satellite images Landsat 7-ETM+ and hydraulic model HEC-RAS. Case study: The Jijia River, Slobozia-Dângeni section. In Proceedings of the 5th International Scientific Conference Geobalcanica, Sofia, Bulgaria, 13-14 June 2019; Volume 5, pp. 619-625. [CrossRef]

40. Urzica, A.; Mihu-Pintilie, A.; Huţanu, E.; Stoleriu, C.C. Using HEC-RAS software to analyze 6 parameters regarding the manifestation of flood events. A case study of Baseu river lowland, NE Romania. In Proceedings of the 5th International Scientific Conference Geobalcanica, Sofia, Bulgaria, 13-14 June 2019; Volume 5, pp. 643-650. [CrossRef]

41. Tanaka, T.; Tachikawa, Y.; Ichikawa, Y.; Yorozu, K. An automatic domain updating method for fast 2-dimensional flood-inundation modeling. Environ. Model. Softw. 2019, 116, 110-118. [CrossRef]

42. Schumann, G.J.P.; Neal, J.C.; Voisin, N.; Andreadis, K.M.; Pappenberger, F.; Phanthuwongpakdee, N.; Hall, A.C.; Bates, P.D. A first large-scale flood inundation forecasting model. Water Resour. Res. 2013, 49, 6248-6257. [CrossRef]

43. SMIS-CSNR 17945 (Water Administration Prut-Bîrlad, Romania) Works for Reducing the Flood Risk in Prut-Bîrlad Basin. Available online: http://www.romair.ro (accessed on 4 March 2020).

44. NARW (National Administration "Romanian Waters")—Hazard and risk flood maps. Available online: http://gis2.rowater.ro:8989/flood/ (accessed on 4 March 2020).

45. Lea, D.; Yeonsu, K.; Hyunuk, A. Case study of HEC-RAS 1D - 2D coupling simulation: 2002 Baeksan flood event in Korea. Water 2019, 11, 2048. [CrossRef]

46. Dimitriadis, P.; Tegos, A.; Oikonomou, A.; Pagana, V.; Koukouvinos, A.; Mamassis, N.; Koutsoyiannis, D.; Efstratiadis, A. Comparative evaluation of 1D and quasi-2D hydraulic models based on benchmark and real-world applications for uncertainty assessment in flood mapping. J. Hydrol. 2016, 534, 478-492. [CrossRef]

47. Md Ali, A.; Solomatine, D.P.; Di Baldassarre, G. Assessing the impact of different sources of topographic data on 1-D hydraulic modeling of floods. Hydrol. Earth Syst. Sci. 2015, 19, 631-643. [CrossRef]

48. Kadir, M.A.A.; Abustan, I.; Razak, M.F.A. 2D Flood inundation simulation based on a large scale physical model using course numerical grid method. Int. J. Geomat. 2019, 17, 230-236. [CrossRef]

49. Hankin, B.; Metcalfe, P.; Beven, K.; Chappel, N.A. Integration of hillslope hydrology and 2D hydraulic modeling for natural flood management. Hydrol. Res. 2019, 50, 1535-1548. [CrossRef] 
50. Huţanu, E.; Urzica, A.; Enea, A. Evaluation of Damages Caused by Floods, based on Satellite Images. Case Study: Jijia River, Slobozia-Dângeni Sector, July 2010. Present Environ. Sustain. Dev. 2018, 12, 135-146. [CrossRef]

51. Băcăuanu, V. Câmpia Moldovei. Studiu Geomorfologic; Editura Academiei Romane: Bucharest, Romania, 1968; pp. 1-222.

52. Haase, D.; Fink, J.; Haase, G.; Ruske, R.; Pécsi, M.; Richter, H.; Altermann, M.; Jäger, K.-D. Loess in Europe-Its spatial distribution based on a European loess map, scale 1:250,000. Quat. Sci. Rev. 2007, 26, 1301-1312. [CrossRef]

53. Buruiană, D.; Apostol, L.; Machidon, O.; Buruiană, M. The identification of vulnerable localities to flash flows from the inferior basin of Jijia River through the physiographic method. In Proceedings of the Annals of DAAM for 2012 \& 23rd DAAAM International Symposium on Intelligent Manufacturing and Automation 2012, Vienna, Austria, 24-27 October 2012; Volume 2, pp. 707-710.

54. INSSE. The 2011 Population and Housing Census-Statistic Action of Strategic Importance for România. Available online: http://colectaredate.insse.ro/phc/public.do?siteLang=en (accessed on 6 March 2020).

55. Iosub, M.; Minea, I.; Chelariu, O.E.; Ursu, A. Assessment of flash flood susceptibility potential in Moldavian Plain (Romania). J. Flood Risk Manag. 2020, e12588. [CrossRef]

56. Silva-Coira, F.; Paramá, J.R.; Ladra, S.; López, J.R.; Gutiérrez, G. Efficient processing of raster and vector data. PLoS ONE 2020, 15, e0226943. [CrossRef] [PubMed]

57. Edwards, P.J.; Watson, E.A.; Wood, F. Toward a Better Understanding of Recurrence Intervals, Bankfull, and Their Importance. J. Contemp. Water Res. Educ. 2019, 166, 35-45. [CrossRef]

58. Read, L.K.; Vogel, R.M. Hazard function analysis for flood planning under nonstationarity. Water Resour. Res. 2016, 52, 4116-4131. [CrossRef]

59. Nguyen, T.; In-Na, N. Plotting formula for Pearson type III distribution considering historical information. Environ. Monit. Assess. 1992, 23, 137-152. [CrossRef] [PubMed]

60. Copernicus Land Monitoring Service (CLMS) - Part of the Copernicus Programme. Riparian Zone Database. Available online: https://land.copernicus.eu/local/riparian-zones (accessed on 9 March 2020).

61. OpenStreetMap. Available online: https://www.openstreetmap.org/ (accessed on 12 February 2020).

62. Copernicus Land Monitoring Service (CLMS) - Part of the Copernicus Programme. CORINE Land Cover 2018. Available online: https://land.copernicus.eu/pan-european/corine-land-cover/clc2018 (accessed on 9 March 2020).

63. Papaioannou, G.; Efstratiadis, A.; Vasiliades, L.; Loukas, A.; Papalexiou, S.M.; Koukouvinos, A.; Tsoukalas, I.; Kossieris, P. An Operational Method for Flood Directive Implementation in Ungauged Urban Areas. Hydrology 2018, 5, 24. [CrossRef]

64. Patel, C.G.; Gundaliya, P.J. Floodplain delineation using HEC-RAS model-A case study of Surat City. Open J. Modern Hydrol. 2016, 6, 34-42. [CrossRef]

65. Quiroga, V.M.; Kure, S.; Udo, K.; Mano, A. Application of 2D numerical simulation for the analysis of the February 2014 Bolivian Amazonia flood: Application of the new HEC-RAS version 5. Ribagua 2016, 3, $25-33$. [CrossRef]

66. INSPIRE Geoportal Access to European Spatial Data. Available online: http://inspire-geoportal.ec.europa.eu (accessed on 13 March 2020).

(C) 2020 by the authors. Licensee MDPI, Basel, Switzerland. This article is an open access article distributed under the terms and conditions of the Creative Commons Attribution (CC BY) license (http://creativecommons.org/licenses/by/4.0/). 